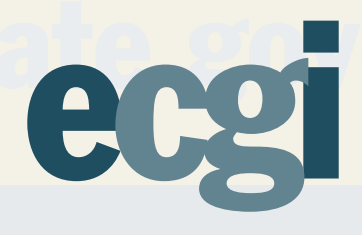

\title{
An Institutional Theory of Corporate Regulation
}

Law Working Paper N 400/2018

April 2018

\section{Iris H-Y Chiu}

University College London and ECGI

(C) Iris H-Y Chiu 2018. All rights reserved. Short sections of text, not to exceed two paragraphs, may be quoted without explicit permission provided that full credit, including (C) notice, is given to the source.

This paper can be downloaded without charge from: http://ssrn.com/abstract_id=3122029

www.ecgi.org/wp 


\section{An Institutional Theory of Corporate Regulation}

Working Paper $\mathrm{N}^{\circ} 400 / 2018$

April 2018

Iris H-Y Chiu

I thank Richard Moorhead for his comments on an earlier draft and all errors and omissions are mine.

(C) Iris H-Y Chiu 2018. All rights reserved. Short sections of text, not to exceed two paragraphs, may be quoted without explicit permission provided that full credit, including $\mathbb{C}$ notice, is given to the source. 
The regulation of corporate behaviour has persisted in spite of peaks of neo-liberalism in many developed jurisdictions of the world, including the UK. This paradox is described as 'regulatory capitalism' by a number of scholars. Of particular note is the proliferation of corporate regulation to govern 'socially responsible' behaviour in recent legislative reforms in the EU and UK. In seeking to answer the broader question of whether corporate regulation indeed effectively governs and moderates corporate behaviour, this paper focuses on the nature of corporate regulation. Although different pieces of corporate regulation purport to achieve different objectives and impose different types of obligations, this paper offers an institutional account of corporate regulation, specifically in relation to the UK's regulatory capitalism, as the UK is typically held up as having a liberal market economy (which is broadly similar to the US). We argue that the nature and effectiveness of corporate regulation crucially depends on the nature of 'regulatory capitalism' in the type of economic order under discussion. Hence the study of the UK's economic order and its efforts in introducing corporate regulation to change corporate behaviour holds lessons more generally for corporate regulation in economies that share similar features. The examination in this article provides an overarching framework for distilling the achievements and limitations of corporate regulation in such economic contexts. First, the paper clarifies that regulatory capitalism in the UK is characterised by three key tenets which reflect the spirit of the liberal market economy embraced here. Over time, gaps have been revealed in the achievements of these tenets of regulatory capitalism, particularly in relation to social expectations of the regulation of corporate behaviour. These gaps have become the subject of debates in the realm of 'corporate social responsibility' (CSR), where business, civil society and the state frame the expectations of corporate behaviour in contested ways such as in relation to scope, motivations, theoretical and practical premises. In the aftermath of the global financial crisis 2007-9, we observe increasing legalisation in the EU and UK of CSR issues, framed in 'new governance' regulatory techniques. They hold promise for change in corporate conduct through deeper forms of corporate engagement and accountability but they appear at the same time relatively undemanding and susceptible to cosmetic compliance. By discussing key examples in new corporate regulation reforms in the EU and UK, we seek to understand why recent corporate regulation reforms seem to offer mixed and in some cases, relatively limited achievements in governing corporate behaviour. We argue that the institutional account of corporate regulation continues to be able to explain regulatory weaknesses and limited achievements, in spite of the deployment of 'new governance' regulatory techniques. This is because 'new governance' regulatory techniques are implemented within the ethos of regulatory capitalism which limits their potential to introduce paradigm shifts. However the limitations of these regulatory reforms highlight more sharply the institutional shifts that are needed in order to connect the efficacy of corporate regulation with meeting social expectations.
\end{abstract}

Keywords: corporate regulation, corporate social responsibility, new governance, liberal market economy, anti-bribery, supply chain, tax avoidance, mandatory disclosure, stakeholders

JEL Classifications: G3, K2

Iris H-Y Chiu

Professor of Corporate Law and Financial Regulation

University College London, Faculty of Laws

415 Bentham House Endsleigh Gardens

London WC1H 0EG, United Kingdom

e-mail: hse-yu.chiu@ucl.ac.uk 


\section{An Institutional Theory of Corporate Regulation}

\section{Iris H-Y Chiu*}

\section{Introduction}

The regulation of corporate behaviour has persisted in spite of peaks of neo-liberalism in many global jurisdictions, including the UK. This paradox is described as 'regulatory capitalism'. ${ }^{1}$ of particular note is the proliferation of corporate regulation to govern 'socially responsible' behaviour in recent reforms in the EU and UK.

The inquiry in this paper is what corporate regulation has achieved over recent decades and contributes to the discourse on 'regulatory effectiveness'. A recent paper in empirical research finds that in post-1970 common law countries, corporate regulation is reactive in nature, and has little role to play in moderating future corporate behaviour. ${ }^{2}$ Despite the overall pessimistic finding, we observe the indefatigable advancement of corporate regulation, from product liability ${ }^{3}$ and environmental degradation, ${ }^{4}$ to the recent surge in corporate regulation dealing human rights, corruption and stakeholders. ${ }^{5}$ Can 'regulatory effectiveness' really be dismissed? We recognise that regulation can be introduced for a variety of reasons including protectionist purposes ${ }^{6}$ but we focus here on the objective of moderating corporate excesses or changing corporate behaviour. ${ }^{7}$ Even as regulation is susceptible to being captured, ${ }^{8}$ reactive or weak, many commentators ${ }^{9}$ continue to affirm its importance in meeting public interest objectives, supplying public and collective goods, meeting distributive and welfare objectives and responding to the needs of society.

The precise weighting of regulatory effectiveness is not what this paper sets out to do, rather, we argue that an institutional account of corporate regulation is necessary to illuminate the issue of regulatory effectiveness in changing corporate behaviour. We seek to give an account of how corporate regulation works as an institution of our capitalist tradition, in order to appraise its achievements and limitations. The institutional account of corporate regulation also sheds light on a number of more specific issues, in particular, the likely 'effectiveness' of a new trend in corporate

\footnotetext{
*Professor of Corporate Law and Financial Regulation, University College London. I thank Richard Moorhead for his comments on an earlier draft and all errors and omissions are mine.

${ }^{1}$ David Levi-Faur, 'The Global Diffusion of Regulatory Capitalism' (2005) 598 The Annals of the American Academy of Political and Social Science 12.

2 Luzi Hail, Ahmed Tahoun and Clare Wang, 'Corporate Scandals and Regulation' (ECGI Working Paper 2017) at http://ecgi.global/sites/default/files/working_papers/documents/hail-tahoun-wangunpixelated_0.pdf.

3 John Wood, 'Consumer Protection: A Case of Successful Regulation' in Peter Drahos (ed), Regulatory Theory (Canberra: ANU Press 2017), ch36.

${ }^{4}$ John Braithwaite and Peter Drahos, 'Contests of Actors' and 'Contests of Principles' in Global Business Regulation (Oxford: OUP, 2000), ch20 and 21; Tony Prosser, 'Comparisons and Conclusions' in The Regulatory Enterprise (Oxford: OUP 2010), ch11.

${ }^{5}$ Section C.

${ }^{6}$ Bubble Act in the $18^{\text {th }}$ century that had the effect of entrenching the power and monopolies of chartered corporations in the UK.

${ }^{7}$ Introduction, Christine Parker and Vibeke Lehmann Nielsen (eds), Explaining Compliance: Business Responses to Regulation (Cheltenham: Edward Elgar 2011).

${ }^{8}$ Public choice theory of regulation, George Stigler, "The Theory of Economic Regulation" (1971) 2 Bell Journal of Economics and Management Science 3, cf Steven Croley, "Theories Of Regulation: Incorporating The Administrative Process" (1998) 98 Columbia Law Review 1.

${ }^{9}$ Cass Sunstein, Valuing Life: Humanizing the Regulatory State (University of Chicago Press, 2014); John Braithwaite, Regulatory Capitalism (Cheltenham: Edward Elgar, 2008).
} 
regulation targeted at the 'social responsibility' aspects of corporate behaviour, ${ }^{10}$ and the achievements and limitations of new regulatory techniques such as 'new governance' ${ }^{\prime 1}$ that support such regulation. We seek to understand why 'new governance' techniques, which have been developed with much promise in respect of governing corporate behaviour, have only been supported by a track record of mixed results.

This article defines the scope of 'corporate regulation' as law that addresses corporate behaviour but not limited to the corporate form or governance. Aguilera et $\mathrm{al}^{12}$ provide a comprehensive mapping of the drivers for corporate behavioural change at the levels of the individual, the firm/organisation, the national/institutional and the supranational. The range of behavioural drivers include individual ethics, organisational pressures and culture, bottom-up third party pressures and incentives, law and regulation, and supranational developments such as international codes and soft law. Corporate regulation is one but an important driver for change in corporate behaviour. ${ }^{13}$ Regulation can, through a variety of techniques, ${ }^{14}$ incentivise or force changes to corporate behaviour. ${ }^{15}$ The regulatory context is also important for developing 'soft law' ${ }^{16}$ and initiatives that complement or co-shape one another for influencing change in corporate behaviour. ${ }^{17}$ Indeed the existence of regulation is often crucial to the success of voluntary, third party or civil society-led initiatives. ${ }^{18}$ Hence in focusing on giving an institutional account of corporate regulation, this article does not marginalise the importance of other types of initiatives. Quite the contrary, it argues that a rich understanding of the institution of corporate regulation is essential to the larger picture of

\footnotetext{
${ }^{10}$ Sections B and C.

${ }^{11}$ Above.

${ }^{12}$ Ruth Aguilera, Deborah Rupp, Cynthia Williams and Jyoti Ganapathi, 'Putting the S Back in Corporate Social Responsibility: A Multilevel Theory of Social Change in Organizations' (2007) 32 Academy of Management Review 836.

13 Jette Knudsen and Dana Brown, 'Why Governments Intervene: Exploring Mixed Motives for Public Policies on Corporate Social Responsibility' (2015) 30 Public Policy and Administration 51; Reinhard Steurer, 'The Role of Governments in Corporate Social Responsibility: Characterising Public Policies on CSR in Europe' (2010) 43 Policy Sciences 49.

${ }^{14}$ Neil Gunningham, 'Regulation: From Traditional to Cooperative' in Shanna Van Slyke et al (eds), Oxford Handbook of White Collar Crime (Oxford: OUP 2016); Laura Albareda, Josep M. Lozano and Tamyko Ysa, 'Public Policies on Corporate Social Responsibility: The Role of Governments in Europe' (2007) 74 Journal of Business Ethics 391.

${ }^{15}$ Parker and Nielsen (eds), Explaining Compliance (2011); Neil Gunningham and Robert Kagan (eds), Regulation and Business Behavior (2005) 27 Law \& Pol'y 213; Ralf Boscheck (ed), Strategies, Markets and Governance: Exploring Commercial and Regulatory Agendas (Cambridge: CUP 2008). Regulation articulates norms and clarifies corporations' 'social licence to operate', Karin Buhmann, 'Public Regulators and CSR: The 'Social Licence to Operate' in Recent United Nations Instruments on Business and Human Rights and the Juridification of CSR' (2016) Journal of Business Ethics, forthcoming) at http://ssrn.com/abstract=2705360; the power of regulatory enforcement is a powerful incentive for behavioural change, Céline Gainet, 'Exploring the Impact of Legal Systems and Financial Structure on Corporate Responsibility' (2010) 95 Journal of Business Ethics 195.

${ }^{16}$ Section B.

${ }^{17}$ Bryan Horrigan, '21st Century Corporate Social Responsibility Trends - An Emerging Comparative Body of Law and Regulation on Corporate Responsibility, Governance, and Sustainability' (2007) 4 McQuarie Journal of Business Law 85; Reinhard Steurer, 'Disentangling governance: A Synoptic View of Regulation by Government, Business, and Civil Society' (2013) 46 Political Sciences 387.

18 Jodi Short and Michael Toffel, 'Making Self-Regulation More Than Merely Symbolic: The Critical Role of the Legal Environment' (2010) 55 Administrative Science Quarterly 361; Min-Dong Lee, 'Configuration of External Influences: The Combined Effects of Institutions and Stakeholders on Corporate Social Responsibility Strategies' (2011) 102 Journal of Business Ethics 281; Ronald Jeurissen, 'Institutional Conditions of Corporate Citizenship' (2004) 53 Journal of Business Ethics 87.
} 
developing and evaluating endeavours by governments, civil society and indeed business, to change corporate behaviour.

Section A explores the development of corporate regulation in the UK as an institution of 'regulatory capitalism'. Corporate regulation is integral to the ethos of the capitalist tradition embraced in many jurisdictions in the world. ${ }^{19}$ We discuss the key tenets and achievements of regulatory capitalism, but also highlight its limitations as crucially defined by our capitalist economic model.

Section B discusses how regulatory limitations have been increasingly exposed and challenged in the social sphere. Calls for corporate social responsibility (CSR) have become louder, entailing developments in the voluntary and largely transnational space, in the form of 'new governance' and 'soft law'. The global financial crisis 2007-9 then brought about a turning point in businessgovernment relations and an unprecedented surge in the legalisation of CSR. Section C analyses this phenomenon in several regulatory reforms introduced in the UK and EU, to shed light on whether such legalisation indicates paradigm-shifts in corporate regulation. We find mixed results and explain our findings in the institutional account of corporate regulation. Section E concludes.

\section{A. Corporate Regulation in the UK as a Phenomenon of Regulatory Capitalism}

\section{The Capitalist Order of the Liberal Market Economy and the Nature of Regulatory Capitalism}

The capitalist economic model in the UK is described as an 'Anglo-liberal' economy ${ }^{20}$ or as termed by the varieties of capitalism literature, a 'liberal market economy'. ${ }^{21}$ Fundamentally, a capitalist economic order upholds the freedom of exchange expressed in market relations, seen as the essential counterpart to political freedom in democratic states. ${ }^{22}$ Markets are regarded as places where individuals seeking to maximise their welfare can make efficient choices based on their individualistic perceptions of opportunity cost. The promotion of free markets can be seen as establishing the necessary conditions for realising economic freedoms and individual success. ${ }^{23}$ The hallmark of the British model is the acceptance of the supremacy of the market in coordinating economic relations whether they are investment, production, distribution or consumption- a phenomenon some call 'market fundamentalism'. ${ }^{24}$ Such market fundamentalism rose to its political peak in the 1980s under the Thatcher governments. ${ }^{25}$ Although markets are not regarded as perfect and the development of law and regulation has played a part in addressing market distortions and failures, ${ }^{26}$ the British model of capitalism today has continued to reflect many features of market fundamentalism. ${ }^{27}$

The importance of marketization of economic relations has profoundly affected the organisation of economic activity in corporations. The corporate sector in Britain was dominated by monopolies

\footnotetext{
19 Levi-Faur, 'The Global Diffusion of Regulatory Capitalism' (2005).

${ }^{20}$ Colin Hay, The Failure of Anglo-Liberal Capitalism (Basingstoke: Palgrave 2013); Colin Hay and Anthony Payne, Civic Capitalism (London: Polity Press, 2015).

${ }^{21}$ 'An Introduction' in Peter A Hall and David Soskice (eds), Varieties of Capitalism: The Institutional Foundations of Comparative Advantage (Oxford: OUP 2001), ch1.

${ }^{22}$ Martin Wolf, 'The Morality of the Market' (2003) 138 Foreign Policy 46.

${ }^{23}$ Hayek's support of the free market in Road to Serfdom (1944) can be reconciled with Amartya Sen's argument that political and economic liberties are key institutions, though not exclusively, for the development of real economic well-being for every individual, Development as Freedom (Oxford: OUP 1999). ${ }^{24}$ Joseph Stiglitz, Freefall: America, Free Markets, and the Sinking of the World Economy (WW Norton \& Co, 2010).

${ }^{25}$ Sally Wheeler, Corporations and the Third Way (Oxford: Hart 2002), p14, 44.

${ }^{26}$ p1-2, John McDermott, Corporate Society (Colorado: Westview 1991).

${ }^{27}$ Hay and Payne, Civic Capitalism (2015); Adair Turner, Just Capitalism (London Macmillan Books, 2001$)$, ch12.
} 
established under Royal Charter until the $19^{\text {th }}$ century, ${ }^{28}$ and family-owned and closely knit companies until the end of the First World War. ${ }^{29}$ The organisation of economic activity within a corporate structure also had social and political implications..$^{30}$ The corporation ushered in an economic society in terms of structuring economic relations ${ }^{31}$ and bringing about social change such as social mobility. ${ }^{32}$ From the end of the Second World War, the marketization of the corporation developed incrementally with the rise in the market for corporate control and ownership of shares. ${ }^{33}$ The promotion of market fundamentalism peaked with the dismantling of Keynesian economic policies in the 1980s, as the British state relinquished direct economic agency, privatised nationalised industries ${ }^{34}$ and pursued a policy of enhancing corporate competitiveness. This era marked a decisive shift in the characterisation of British corporations as market-based actors, and has had a lasting effect upon corporate behaviour. Corporations as market-based actors pursue individualistic and 'rational' micro-economic behaviour, profoundly changing the way economic relationships are structured within and beyond the corporation, ${ }^{35}$ and how they perceive their roles in society. ${ }^{36}$ The Thatcher government promoted the structuring of economic relations through the market, and market supremacy trumped organised relations between firms and labour, marking the start of decline of the institution of collective bargaining. ${ }^{37}$ Since the 1980 s, government involvement in economic activity declined, and the private sector clearly came to the forefront to provide goods and services and carry out innovation.

Paradoxically, the state grew concomitantly in terms of its regulatory remit and apparatus. ${ }^{38}$ It is a myth that systemic deregulation had taken place. Instead, this is an age of 'regulatory capitalism'. ${ }^{39}$ Regulatory capitalism may be seen as the balance to market fundamentalism. The role of the state in economic policy is clarified as that of 'steering' while the private sector is responsible for 'rowing'. ${ }^{40}$ The objectives of regulation are to steer away from the problems that unbridled markets give rise to, such as market failures ${ }^{41}$ and to provide collective goods. ${ }^{42}$ The nature of regulation has also become infused with economic analysis and market-based concepts. ${ }^{43}$

\footnotetext{
${ }^{28}$ Eg East India and South Sea Companies, protected by the Bubble Act; Brian Cheffins, Corporate Ownership and Control: British Businesses Transformed (Oxford: OUP 2010), ch6.

${ }^{29}$ Above, ch8-10.

${ }^{30}$ The Cadburys merged economic enterprise with social provision for their employees, C Dellheim, 'The Creation of a Company Culture: The Cadburys 1861-1931' (1987) 92 American Historical Review 13.

${ }^{31}$ McDermott, Corporate Society (1991).

32 Seymour Martin Lipset and Reinhard Bendix, Social Mobility in Industrial Society (Transaction Publishers 1991).

${ }^{33}$ Cheffins, Corporate Ownership (2010), chs 8-10.

${ }^{34}$ Stephen Young, 'The Nature of Privatisation in Britain, 1979-85' (1986) 9 Western European Politics 235.

${ }^{35}$ corporations may choose to frame their relationships in singularly economic terms, prizing choice and efficiency such as 'exit' over social values such as commitment and 'voice', Albert O Hirschmann, Exit, Voice and Loyalty (Mass: Harvard University Press, 1970).

${ }^{36}$ Shifting away from 'values ethics'-based roles, Wheeler, Corporations and the Third Way (2002); Willian W Bratton, 'The Separation of Corporate Law from Social Welfare' (2017) 74 Washington and Lee Review 2.

${ }^{37}$ Richard F Disney, Amanda Gosling and Stephen J Machin, 'British Unions in Decline: An Examination of the 1980s Fall in Trade Union Recognition' (NBER Working Paper 2001), https://papers.ssrn.com/sol3/papers.cfm?abstract_id=250345.

${ }^{38}$ Michael Moran, 'The Rise of the Regulatory State in Britain' (2001) 54 Parliamentary Affairs 19.

${ }^{39}$ Braithwaite, Regulatory Capitalism (2008), ch1.

${ }^{40}$ Above; Levi-Faur, 'The Global Diffusion' (2005).

${ }^{41}$ Eg information asymmetry, oligopolistic structures etc, Anthony Ogus, Regulation (Oxford: Clarendon Press 1994); Bronwen Morgan and Karen Yeung, An Introduction to Law and Regulation (Cambridge: CUP 2007), pp18-25; 47-53.
} 
The economically-driven model of regulation can be seen, for example, in the regulation of utilities ${ }^{44}$ which focuses on anti-competitive behaviour, and in financial regulation ${ }^{45}$ focused on overcoming market failures such as information asymmetries. The growth of many regulatory agencies ${ }^{46}$ is premised upon the need to correct market failures so as to support optimal market outcomes. The government has since 2004 committed to better and efficient regulation, ${ }^{47}$ including refraining from regulatory intervention in favour of 'economic progress' ${ }^{48}$

Policy-making and regulatory technique are infused with 'market-based' wisdom, as regulators consider the balance of risk/harm to determine the extent of intervention, ${ }^{49}$ the need for regulatory resources to be allocated according to risk-based regulation, ${ }^{50}$ and the use of cost-benefit analyse ${ }^{51}$ (however imperfectly ${ }^{52}$ ) to account for regulatory initiatives.

Regulation has also been introduced to govern industries where business activity has resulted in social harms, ${ }^{53}$ producing regulatory regimes that target a mixture of economic and social demands. ${ }^{54}$ In sum, regulatory capitalism is heavily infused with the economic intellectual tradition, as economic behaviour and its control, become increasingly framed as incentive-based. Although this is not the only paradigm in which regulation is designed and implemented, regulatory capitalism

\footnotetext{
${ }^{42}$ Eg. prevention of social harm, Edward L Glaeser and Andrei Schleifer, 'The Rise of the Regulatory State' (2003) 41 Journal of Economic Literature 401.

${ }^{43}$ The 'Law and Economics' school of thought, Robert van Horn and Philip Mirowski, 'The Rise of the Chicago School of Economics' in Philip Mirowski and Dieter Plehwe (eds), The Road from Mont Pelerin (Mass: Harvard University Press 2009). Ogus, Regulation (2004); Mathis Klaus (ed), Law and Economics in Europe (Heidelberg: Springer, 2014); cf Katja Lagenbucher, Economic Transplants: On Law-making for Corporations and Financial Markets (Cambridge: CUP, 2017).

44 John Vickers and George Yarrow, 'The Regulation of Privatised Firms in Britain' (1988) 32 European Economic Review 465; Prosser, Regulatory Enterprise (2010), ch9.

${ }^{45}$ FCA, Economics for Effective Regulation (March 2016); John Armour et al, Principles of Financial Regulation (Oxford: OUP 2016), ch1.

${ }^{46}$ Levi-Faur, 'The Global Diffusion' (2005); Giandomenico Majone, 'The Rise of the Regulatory State in Europe' (1994) 17 Western European Politics 77 on European developments.

${ }^{47}$ The institution of the Better Regulation Task Force in 2006, then Better Regulation Commission in 2008-9 to advise the government in rational and efficient regulatory design. This work continues in the Regulatory Policy Committee, https://www.gov.uk/government/organisations/regulatory-policy-committee.

${ }^{48}$ Hampton Review on Regulation Inspections and Enforcement (2004) at http://webarchive.nationalarchives.gov.uk/20070701131038/http://www.hmtreasury.gov.uk/media/7/F/bud05hamptonv1.pdf.

${ }^{49}$ Christopher Hood, Henry Rothstein and Robert Baldwin, The Government of Risk: Understanding Risk Regulation Regimes (Oxford: OUP 2004).

${ }^{50}$ Julia Black, The Development of Risk-based Regulation in Financial Services: Canada, the UK and Australia-a Research Report (London: ECRC Centre for the Analysis of Risk and Regulation, LSE 2004).

51 Julie Froud and Anthony Ogus, 'Rational Social Regulation and Compliance Cost Assessment' (1996) 74 Public Administration 221, Cass Sunstein, "The Cost-Benefit State" (Coase-Sandor Institute for Law \& Economics Working Paper No. 39, 1996).

52 Jonathan Masur and Eric Posner, 'Unquantified Benefits and the Problem of Regulation Under Uncertainty' (2016) 102 Cornell Law Review 87.

53 Braithwaite, Regulatory Capitalism (2008), ch1, 2.

${ }^{54}$ Prosser, 'Comparisons and Conclusions' in Regulatory Enterprise (2010), ch11; Braithwaite and Drahos, 'Contests of Actors' and 'Contests of Principles' in Global Business Regulation (2000), ch20 and 21.
} 
in the UK can on the whole be regarded as neo-liberal in nature, ${ }^{55}$ supporting the marketised economic order. ${ }^{56}$

\section{The Three Tenets of Corporate Regulation}

We argue that corporate regulation in the UK's liberal market economy is underpinned by the ethos in regulatory capitalism, giving rise to three tenets. First, the law for the organisation and structuring of corporations, company law, (a) respects corporations as private economic organisations; and (b) facilitates the economic freedoms of freely associating agents in the corporation as a 'contractarian organisation' that manages its internal efficiencies. ${ }^{57}$ The role of mandatory law is to provide an efficient framework to meet the needs of order, balance and accountability in the private 'administrative' franchise that is the company. ${ }^{58}$ Company law essentially constitutes a private framework of governance centred upon management control ${ }^{59}$ subject to shareholder primacy. ${ }^{60}$ This is consonant with the notions of theoretical efficiency supported by commentators ${ }^{61}$ in the economics of organisation. Company law has been shaped largely by internal efficiency and governance needs, bearing little relation to social policy. ${ }^{62}$ As the New Labour government put it in relation to reforming company law after they came into power, company law reforms carried out in 2006 were about modernising the company as a business vehicle that promotes enterprise and the right conditions for investment and employment. ${ }^{63}$

Second, a major source of corporate regulation is securities regulation for publicly listed corporations. Such regulation is focused on corporations' responsibilities to the markets that provide them with capital, and facilitates market-based discipline carried out by investors. Securities

\footnotetext{
${ }^{55}$ Peter Drahos, 'Regulatory Capitalism, Globalization and the End of History' (2014) at http://ssrn.com/abstract=2449920.

${ }^{56}$ Prosser, 'Regulating the Regulators' in Regulatory Enterprise (2010), ch10.
}

${ }^{57}$ Company law reflecting parties' hypothetical bargains, William Klein, "The Modern Business Organization: Bargaining Under Constraints" (1982) 91 Yale Law Journal 1521; Frank Easterbrook and Daniel Fischel, "The Corporate Contract" in The Economic Structure of Corporate Law (Cambridge Mass: Harvard University Press 1991). Marc Moore, 'Private Ordering and Public Policy: the Paradoxical Foundations of Contractarianism' (2014) 34 OJLS 693.

${ }^{58}$ Marc Moore, Corporate Governance in the Shadow of the State (Oxford: Hart 2013).

${ }^{59}$ Art 3, Model Articles for Private and Public Companies Regulations 2008.

${ }^{60}$ Andrew Keay, 'Shareholder Primacy in Corporate Law : Can it Survive? Should it Survive?' (2009), http://ssrn.com/abstract=1498065; at the global level, shareholder primacy is argued to be the dominant model of the corporate economy, Henry Hansmann and Reiner Kraakman, 'The End of History for Corporate Law' (2000) 89 Georgetown Law Journal 439.

${ }^{61}$ The importance of shareholders is supported by the economic 'residual claimants' analysis, Armen Alchian and Harold Demsetz, "Production, Information Costs and Economic Organisation" (1972) 62 American Economic Rev 777; Oliver Williamson, “Corporate Governance” (1984) 93 Yale Law Journal 1197. Shareholder primacy addresses the agency problem of separation of ownership from control, Easterbrook and Fischel, "The Corporate Contract" above; Michael C Jensen and William H Meckling, 'Theory of the Firm: Managerial Behaviour, Agency Costs and Ownership Structure' (1976) 3 Journal of Financial Economics 305.

${ }^{62}$ Lyman Johnson, 'Corporate Law and the History of Corporate Social Responsibility' (2017), http://ssrn.com/abstract=2962432; Jingchen Zhao, 'Promoting More Socially Responsible Corporations Through a Corporate Law Regulatory Framework' (2017) 37 Legal Studies 103. Contrast with the coordinated market economy in Germany that adopts co-determination in corporate governance, Sigurt Vitols, 'Varieties of Corporate Governance: Comparing Germany and the UK' in Hall and Soskice (eds), Varieties of Capitalism (2001), ch10.

63 DTI, Company Law Reform White Paper (2005), ch2, at

http://webarchive.nationalarchives.gov.uk/20060214052726/http://www.dti.gov.uk/cld/WhitePaper.htm. 
regulation was pioneered in the US as socio-economic reform, ${ }^{64}$ but has since become characterised as chiefly economic in nature since the 1980 s, as theoretical commentaries on securities regulation revolve around the efficiency of securities markets for securing investor protection. ${ }^{65}$ Such a basis has also driven the development of EU (and UK) securities regulation, ${ }^{66}$ culminating in major harmonisation reforms in the early millennium. ${ }^{67}$

Securities regulation supports market-based discipline for publicly listed corporations by their investors, an important tenet in a well-functioning capital market. Investors could exercise their discipline by supporting a market for corporate control, as a means to change corporate management. ${ }^{68}$ They could also choose to be activist and build up stakes in a company in order to exercise voice, ${ }^{69}$ in the 'market for corporate influence' ${ }^{70}$ The marketization of investment relations between the company and shareholders has become the chief (and private) means for structuring the company's internal governance. Thus, when corporate scandals erupted in the early 1990s in relation to internal fraud and financial mis-reporting on securities markets, ${ }^{71}$ the key cure was seen to be investor discipline and scrutiny. ${ }^{72}$ The UK charted a regime of business-led soft law for the corporate governance of listed companies. ${ }^{73}$ Best practices in corporate governance are now enshrined within a Code ${ }^{74}$ that applies on a comply-or-explain basis to publicly traded companies. ${ }^{75}$ The corporate governance of these companies is framed as a matter for shareholders to scrutinise, ${ }^{76}$ neutralising the social ramifications of the scandals in question. This tradition has continued despite

\footnotetext{
${ }^{64}$ New Deal reforms after the Great Depression, Michael Parrish, Securities Regulation and the New Deal (Yale University Press, 1970). Securities regulation is policed and enforced by a new Securities and Exchange Commission, representing a new 'constitutional' bargain between state, markets, business and citizenry, Cass Sunstein, 'Constitutionalism After the New Deal' (1987) 101 Harvard Law Review 421.

65 John Coffee Jnr, 'Market Failure and the Economic Case for a Mandatory Disclosure System' (1984) 70 Virginia Law Review 717.

${ }^{66} \mathrm{ch} 1$, Iris H-Y Chiu, Regulatory Convergence in EU Securities Regulation (The Hague: Kluwer Law International 2008).

${ }^{67}$ Final Report of the Committee of Wise Men on the Regulation of European Securities Markets (15 Feb 2001), at http://europa.eu.int/comm/internal market/securities/lamfalussy/index en.htm, the Prospectus Directive 2003; Transparency Directive 2004; Markets Abuse Directive 2003 etc. Eilis Ferran, Building an EU Securities Market (Cambridge: CUP 2004).

${ }^{68}$ Michael Hensen and Richard Ruback, 'The Market for Corporate Control: The Scientific Evidence' (1983) 11 Journal of Financial Economics 5; Gregg Jarrell et al, 'The Market for Corporate Control: The Empirical Evidence Since 1980' (1988) 2 Journal of Economic Perspectives 49.

${ }^{69}$ Iris H-Y Chiu, The Foundations and Anatomy of Shareholder Activism (Oxford: Hart 2008).

70 John Armour and Brian Cheffins, 'The Rise and Fall (?) of Shareholder Activism by Hedge Funds' (2012) 14 Journal of Alternative Investments 17; Paul Rose, 'Shareholder Proposals in the Market for Corporate Influence' (2014) 66 Florida Law Review 2179 on shareholder proposals constituting a market for corporate influence.

${ }^{71}$ The fall of the Polly Peck Group and BCCl.

${ }^{72}$ Adrian Cadbury, Financial Aspects of Corporate Governance (1992).

${ }^{73}$ The UK Corporate Governance Code, at https://www.frc.org.uk/getattachment/ca7e94c4-b9a9-49e2-a824ad76a322873c/UK-Corporate-Governance-Code-April-2016.pdf.

${ }^{74}$ Above.

${ }^{75}$ On the efficacy of comply-or-explain, see Antione Faure-Grimaud, Sridhar Arcot and Valentina Bruno, "Corporate Governance in the UK: Is the Comply or Explain Approach Working?" (2005) at “http://eprints.Ise.ac.uk/24673/1/dp581_Corporate_Governance_at_LSE_001.pdf; lain MacNeil and Xiao Li, "“Comply or Explain": Market Discipline and Non-Compliance with the Combined Code" (2006) 14 Corporate Governance 286.

${ }^{76}$ paras 6.6, 6.16, Cadbury, Financial Aspects (1992). Vanessa Finch, "Corporate Governance and Cadbury: Selfregulation and Alternatives" (1994) JBL 51.
} 
the findings of the Myners ${ }^{77}$ and Walker Reports ${ }^{78}$ relating to the relative passivity of institutional investors. Business and markets continue to support shareholder centricity in market discipline ${ }^{79} \mathrm{a}$ position that policy-makers have been willing to endorse ${ }^{80}$ Investor primacy has brought about a marketised model profoundly shaping corporate governance, objectives ${ }^{81}$ and the nature of the corporation. ${ }^{82}$

Nevertheless, 'business regulation' has been developed to effect economic or social policy that affect business or commercial activity. ${ }^{83}$ These are often externally $y^{84}$ addressed to corporations and other economic actors but do not intervene in the private spheres of corporate objectives or governance. For example, market failures such as mis-selling has led to a burst in global consumer protection regulation. ${ }^{85}$ Product safety has been refined by private law in liability ${ }^{86}$ as well as regulatory standards and enforcement, ${ }^{87}$ extending to crucial areas such as food ${ }^{88}$ and drugs, ${ }^{89}$ especially in the wake of scandals such as the BSE scandal ${ }^{90}$ and the thalidomide scandal. ${ }^{91}$ Although social protection against poor commercial practices underlies these regulatory reforms, such business regulation crucially supports market capitalism as consumer confidence is maintained. ${ }^{92}$

Further, as the de-socialisation of labour-firm relations has taken place in the $1980 \mathrm{~s}^{93}$ regulatory policy provides the necessary balances to inequalities in employment relationships not corrected by labour markets. Employee protection legislation developed in anti-discrimination, health and safety, minimum wage and other contractual rights. ${ }^{94}$ Drahos and Braithwaite ${ }^{95}$ also observe the rise in environmental protection legislation particularly in respect of clean air and water, as regulatory capitalism addresses the externalities caused by business activity. These reforms are a mixture of

\footnotetext{
77 Paul Myners, Institutional Investment in the UK: A Review (2001).

${ }^{78}$ David Walker, A Review of Corporate Governance in Banks and Financial Institutions (2009).

${ }^{79}$ The Institutional Shareholders Committee's first Stewardship Principles became adopted as the UK Stewardship Code by the Financial Reporting Council.

${ }^{80}$ UK Stewardship Code setting out optimal principles for shareholder engagement with companies, Iris $\mathrm{H}-\mathrm{Y}$ Chiu, 'Turning Institutional Investors into "Stewards"- Exploring the Meaning and Objectives in "Stewardship"' (2013) Current Legal Problems 1.

${ }^{81}$ Shareholder primacy, see n60.

${ }^{82}$ The corporation as a tradeable stock, Karen Ho, 'Corporate Nostalgia? Managerial Capitalism from a Contemporary Perspective' in Greg Urban (ed), Corporations and Citizenship (University of Pennsylvania Press 2014).

${ }^{83}$ Braithwaite and Drahos, Global Business Regulation (2000).

${ }^{84}$ Johnson, 'Law and the History' (2013).

${ }^{85}$ Wood, 'Consumer Protection' in Drahos (ed), Regulatory Theory (2017).

${ }^{86}$ Duncan Fairgrieve and Richard S Goldberg, Product Liability (Oxford: OUP 2018), Parts II, III; Maria Lee, 'Safety, Regulation and Tort: Fault in Context' (2011) 74 MLR 555.

${ }^{87}$ Consumer Protection Act 1987; Trade Descriptions Act 1968.

${ }^{88}$ Prosser, 'The Food Standards Agency' in The Regulatory Enterprise (2010) at ch3.

${ }^{89}$ Largely centralised under the European Medicines Agency, for the US, Braithwaite and Drahos, n54.

90 'Mad Cow Disease', The Guardian (29 Oct 2000) at https://www.theguardian.com/uk/2000/oct/29/bse.focus1.

${ }^{91}$ Bara Fintel, Athena Samaras, Edson Carias, 'The Thalidomide Tragedy: Lessons for Drug Safety and Regulation' (July 2009) Helix at https://helix.northwestern.edu/article/thalidomide-tragedy-lessons-drugsafety-and-regulation.

92 Steven Shavell, 'Liability for Harm versus Regulation of Safety' (1983) Journal of Legal Studies 357.

${ }^{93}$ Simon Deakin, 'Legal Origin, Juridical Form and Industrialization in Historical Perspective: The Case of the Employment Contract and the Joint-Stock Company' (2009) 7 Socio-Economic Review 35.

${ }^{94}$ S. Deakin \& GS Morris, Labour Law $\left(5^{\text {th }}\right.$ ed, 2009).

${ }^{95}$ Braithwaite and Drahos, n54.
} 
social and economic policy, as corporations are forced to internalise the social price of their activities.

Although business regulation intervenes where markets do not work optimally, regulatory policy is highly shaped and influenced by business. In this political economy, corporations act as 'business' collectively, through trade associations ${ }^{96}$ and international networks, ${ }^{97}$ generating epistemic authority and lobbying pressure. ${ }^{98}$ Dignam describes corporate law and securities regulation as shaped by a 'negotiated' regulatory framework between business and government. ${ }^{99}$

The private and shareholder-focused nature of company law, investor-focused securities regulation and the expression of socio-economic policy through external regulation have become relatively 'stable' tenets of corporate regulation. These support (a) the neoliberal economic agenda, as states and business maintain a companion relationship of 'steering' and 'rowing', and (b) the liberal market economy where economic relations are incentive-based and marketised.

\section{Deficiencies and Lacunae}

As market-based actors in an economic model of market fundamentalism, ${ }^{100}$ corporations' have become insularly focused on profit-maximisation and securities market prices, characterised as 'individualistic' pursuits. ${ }^{101}$ The incentives for corporate behaviour tend to cause tensions with the needs of 'collective' good or social expectations. Regulatory capitalism has to an extent addressed harmful corporate conduct, but it tends to uphold a broad scope of economic freedom. Hence, regulatory capitalism is unlikely to address areas where conflicts arise between social expectations and corporations' economic freedoms.

Corporations have marginalised the social and ethical dimensions of corporate behaviour not reflected in 'market value'. ${ }^{102}$ Holistic notions such as the moderation of 'self-interest' by 'moral sentiments' of self-restraint, ${ }^{103}$ or the perspective that a corporation creating economic wealth does so on trust for society ${ }^{104}$ have become squeezed out by market fundamentalism. A profit-chasing culture in many financial firms generated perverse incentives towards excessive risk-taking, ${ }^{105}$

\footnotetext{
${ }^{96}$ Peter Gourevitch, 'Politics and Corporate Governance: What Explains Policy Outcomes?' in Urban (ed), Corporations and Citizenship (2014); Gregory Schaffer, 'Law and Business' in David Coen, Wyn Grant and Graham Wilson (eds), The Oxford Handbook of Business and Government (Oxford: OUP, 2010).

97 Pamela Camerra-Rowe and Michelle Egan, 'International Regulators and Network Governance' in Coen et al (eds), Oxford Handbook of Business and Government (2010), ch17.

${ }^{98}$ Gourevitch, 'Politics and Corporate Governance' (2014).

99 Alan Dignam, “Capturing Corporate Governance: The End of the UK Self-regulating System” (2007) 4 International Journal of Disclosure and Governance 24.

${ }^{100}$ Empirical research finds alignment between national culture such as market fundamentalism and organisational culture in corporations, Geert Hofstede, Gert Jan Hofstede and Michael Minkov, Cultures and Organisations (NY: McGraw-Hill, 2010), pp320-327.

${ }^{101}$ Ho, 'Corporate Nostalgia?' in Urban (ed), Corporations and Citizenship (2014); Wheeler, Corporations and the Third Way (2002).

102 Lee Boldeman, The Cult of the Market (Canberra: ANU Press, 2007), p280.

${ }^{103}$ Reconciling Adam Smith's grand treatises The Wealth of Nations and The Theory of Moral Sentiments, Spencer J Pack, Capitalism as a Moral System: Adam Smith's Critique of the Free Market Economy (Cheltenham: Edward Elgar 2010).

${ }^{104}$ Adolf Berle, Gardiner Means, The Modern Corporation and Private Property (1932; Transaction Publishers, 1991 Rep), p352.

${ }^{105}$ Michael Santoro and Ronald Strauss, Wall Street Values: Business Ethics and the Global Financial Crisis (Cambridge: Cambridge University Press, 2012); Donald Langevoort, 'Chasing the Greased Pig Down Wall Street: A Gatekeeper's Guide to the Psychology, Culture and Ethics of Financial Risk-taking' (2011) 96 Cornell Law Review 1209; House of Lords and House of Commons, Changing Banking for Good (2013) Vols I and II.
} 
culminating in the global financial crisis 2007-9, and also culminated in the scandal of fictitious bank accounts in Wells Fargo. ${ }^{106}$ Many also regard the BP Deepwater Horizon disaster in 2010 as reflecting failures in organisational culture which prized cost-reduction over human safety. ${ }^{107}$

Corporate exploits could often be at the expense of the social dimension, producing 'a-social' behaviour. ${ }^{108}$ Further, Hendry gives an account of how market fundamentalism has made market values central to business operations, so corporations pursuing their business case are merely adhering to the morality of self-interest. ${ }^{109}$ This conception of morality may conflict with human or social conceptions of morality, ${ }^{110}$ giving rise to a 'bimoral' space for negotiation by companies. The bifurcation of 'business morality' from human or social conceptions, ${ }^{111}$ or indeed the marginalisation of the latter ${ }^{112}$ could create a perverse organisational belief system that is morally dysfunctional. ${ }^{113}$

The private nature of corporate objectives does not necessarily engage with ethical or social dimensions. This is criticised as, at the very least the privilege of incorporation reflects a social contract on the basis of state enfranchisement of private activity. ${ }^{114}$ In the absence of regulatory moderation, corporations can adopt 'a-social' and 'bimoral' behaviour where there is a business case. This tendency is further exacerbated by global trends.

The rise in globalisation has been taken advantage of by corporations, bringing profound changes to their economic structures. Corporations now take advantage of multi-jurisdictional footprints and loose networks in contracts and organisation. ${ }^{115}$ Corporate behaviour has become less easy for national policy-makers to regulate, ${ }^{116}$ while the same policy-makers design regulatory regimes to compete in global regulatory competition ${ }^{117}$ even if strong and extra-territorial legislation can be effected. ${ }^{118}$ There is a lack of international law to govern multinational corporate behaviour, ${ }^{119}$ and

\footnotetext{
106 'Wells Fargo fined \$185M for fake accounts; 5,300 were fired' (USA Today, 8 Sep 2016).

${ }^{107}$ Centre for Progressive Reform, 'The BP Catastrophe: When Hobbled Law and Hollow Regulation Leave Americans Unprotected' (2011) at http://ssrn.com/abstract=1817003.

108 Joel Bakan, The Corporation: The Pathological Pursuit of Profit and Power (NY: Free Press 2003).

109 John Hendry, Between Ethics and Enterprise (Oxford: OUP 2004).

110 John Ikerd, 'Sustainable Capitalism: A Matter of Ethics and Morality' (2008) 3 Problems of Sustainable Development 13.

${ }^{111}$ Wim Dubbink and Jeffrey Smith, 'A Political Account of Corporate Moral Responsibility' (2009) 14 Ethical Theory and Moral Practice 223.

112 Jeroen Veldman and Hugh Willmott, 'The Corporation in Management Studies' in Grietje Baars ed, The Corporation (Cambridge: CUP, 2017), ch5.

113 Jerome Want, Corporate Cultures (NY: St Martin's Press, 2006).

${ }^{114}$ David Ciepley, 'Beyond Public and Private: Toward a Political Theory of the Corporation' (2013) 107 American Political Science Review 139.

${ }^{115}$ Päivi Oinas, 'The Many Boundaries of the Firm' in Michael Taylor and Päivi Oinas (eds), Understanding the Firm: Spatial and Organisational Dimensions (Oxford: OUP, 2006), ch2; Sol Piccioto, Regulating Global Corporate Capitalism (Cambridge: CUP 2011), ch4.2.

${ }^{116}$ Peter Spiro, 'Constraining Global Corporate Power: A Short Introduction' (2013) 46 Vand. J. Transnat'I L. 1101; Kenneth Amaeshi, Onyeka Osuji and Paul Nnodim, 'Corporate Social Responsibility in Supply Chains of Global Brands: A Boundaryless Responsibility? "Clarifications, Exceptions and Implications"' (2008) 81 Journal of Business Ethics 223; Tim Büthe, 'Private Regulation in the Global Economy: A (P)review' (2010) 12 Business and Politics 1.

${ }^{117}$ Colin Crouch, 'The Global Firm: The Problem of the Giant Firm in Democratic Capitalism' in Coen et al (eds), Oxford Handbook of Business and Government (2010), ch6.

${ }^{118}$ Foreign Corrupt Practices Act 1977 and Alien Tort Claims Act dating to the $18^{\text {th }}$ century, Susan Kaczmarek and Abraham Newman, 'The Long Arm of the Law: Extraterritoriality and the National Implementation of Foreign Bribery Legislation' (2011) 65 International Organization 745.

${ }^{119}$ William Magnuson, 'Unilateral Corporate Regulation' (2016) 17 Chi. J. Int'I L. 521.
} 
regulatory arbitrage $\mathrm{e}^{120}$ by corporations has flourished in the slow progress towards international harmonisation. ${ }^{121}$

In an 'a-social' paradigm, companies can pursue myopic and economically-driven relations with their constituents as long as financial efficiency is achieved. If employee-firm relations are insularly treated as marketised, issues such as wage justice would be down to contractual bargaining and are not framed as issues of 'social relations'. Further, stakeholders have found it challenging to advance their participation in the corporate law framework underpinned by shareholder primacy. For example, one of the hallmarks of the liberal market economy in the UK is an open market for corporate control. Companies are free to sell out to takeover offerors that meet with shareholder approval even if stakeholders such as employees and suppliers are affected and have no voice in such decisions. ${ }^{122}$ The marketised framing for corporate conduct crowds out social perspectives. UK companies are free to maintain low wages ${ }^{123}$ while giving in to inflated executive compensation, ${ }^{124}$ in accordance with the trends of different labour markets. A marketised framing of such disparities in reward would not allow us to compare apples to oranges in terms of the different wage markets. But a social framing of the disparities in reward would raise the query why the corporate profit pie, which is the product of all workers, should be distributed disproportionately to favour executives and management.

A marketised framing for corporate conduct and decisions can also tolerate certain amoral behaviour if private contracts have been entered 'freely' in the market. Sharp commercial practices that do not fall within consumer regulation may be pursued putting suppliers on insecure terms. ${ }^{125}$ The case of Newton-Sealey $v$ ArmorGroup Services Ltd \& Ors ${ }^{126}$ illustrates how the legality of a contractual arrangement has become disengaged with any sense of social justice. In that case, a retired army officer in the UK was recruited to provide risky security services in a post-conflict zone in Iraq. The contract was framed to be between the Group's Jersey company and the individual, as the Jersey company could exclude liability for negligence in causing personal injury or death. Although UK law outlaws such exclusion clauses, the individual was subject to less protection under Jersey law, the choice of law made possible for the corporation due to its multi-jurisdictional footprint. The individual who was ultimately injured while on duty could not obtain any compensation from the Jersey or the UK parent company. The legitimacy, albeit sharpness of the commercial practice of limiting business risks for the parent company was upheld, as the parent company was free to organise its economic relations and business risks within the available company law framework.

\footnotetext{
${ }^{120}$ Robin Hansen, 'Multinational Enterprise Pursuit of Minimised Liability: Law, International Business Theory and the Prestige Oil Spill' (2008) 26 Berkeley Journal of International Law 410.

${ }^{121}$ Lawrence Tshuma, 'Hierarchies and Government versus Networks and Governance: Competing Regulatory Paradigms in Global Economic Regulation' (2000) 9 Soc. \& Legal Stud. 115.

${ }^{122}$ Hogg v. Cramphorn Ltd [1967]Ch. 254, also the Kraft takeover of Cadbury Plc in the UK, Georgina Tsagas, 'A Long-Term Vision for UK Firms? Revisiting the Target Director's Advisory Role Since the Takeover of Cadbury's PLC' (2014) 14 JCLS 241.

${ }^{123}$ Institute for Public Policy Research Commission on Economic Justice, Time for Change: A New Vision for the British Economy (Sep 2017) at https://www.ippr.org/files/2017-09/cej-interim-report.pdf.

${ }^{124}$ Martin Conyon and Joachim Schwalbach, 'Executive Compensation: Evidence from the UK and Germany' (2000) 33 Long Range Planning 504; Guido Ferranini, Niamh Moloney and Maria-Cristina Ungureanu, 'Executive Remuneration in Crisis: A Critical Assessment of Reforms in Europe' (2015) 15 JCLS 73.

${ }^{125}$ Christel Lane and Reinhard Bachmann, 'The Social Constitution of Trust: Supplier Relations in Britain and Germany' (1996) 17 Organisation Studies 365.

${ }^{126}$ [2008] EWHC 233 (QB).
} 
By maintaining the private and business-focused nature of corporate law, the company can remain impervious to distributional issues while governments face limitations in effecting distributional justice. The liberal market economy is a capitalist order apt to produce distributive inequalities. ${ }^{127}$ Although such inequalities reflect differences in reward for different forms of enterprise or economic behaviour, ${ }^{128}$ it is another matter to merely accept significantly high levels of inequality that have come about in neo-liberal, financialised economies such as the US and UK. ${ }^{129}$ For example, the company is free to recalibrate pension schemes to the financial disadvantage of employees, such as by paying out dividends to shareholders while pension deficits exist. ${ }^{130}$ These loci of distributional injustices are now attracting policy attention, as Section B discusses. ${ }^{131}$ Market primacy cannot address such inequalities as market prices are often flawed and do not perfectly reflect social cost. ${ }^{132}$ For example, in the Newton-Sealey case, the wages paid to the employee arguably do not fully internalise the risks to the individual and his family.

It is arguable that the very social good of having corporate forms organise productive economic activity is itself becoming questionable. This problem is explored in Kay's review ${ }^{133}$ undertaken for the British government with regard to how long-termism, i.e. the social good of corporate wealth creation for all economic stakeholders in the long term) is being undermined by stock market shorttermism. ${ }^{134}$ As investors 'discipline' corporations by exit or voice depending on quarterly corporate performance, corporate strategies become attuned to the short-term and are financially-driven, undermining visions and strategic investment for the long-term. ${ }^{135}$

The three tenets of corporate regulation are most sharply felt where social objectives are in conflict with market-based incentives. By leaving markets to achieve their allocative purposes, governments have a limited arsenal in addressing social inequalities or bimoral (but legal) behaviour perpetuated

${ }^{127}$ Roger Bootle, The Trouble with Markets (London: Nicholas Brealey Publishing: 2012); G Mulgan, 'The Essence of Capitalism' in The Locust and the Bee (Princeton University Press 2013), ch3; Thomas Piketty, Capital in the Twenty-first Century (Mass: Harvard University Press, 2014).

${ }_{128}$ Israel Kirzner, Discovery, Capitalism and Distributive Justice (Indianopolis: Liberty Fund 2016).

${ }^{129}$ Amartya Sen articulates the need for economic justice to be prized above the relentless logic of liberal market freedoms, "Markets and Freedoms: Achievements and Limitations of the Market Mechanism in Promoting Individual Freedoms" (Oxford Economic Papers, 1993); Zafar Iqbalet al, 'The Current Crisis of Capitalism' (2012) 9 Policy Perspectives 65.

${ }^{130}$ Eg shifting from defined-benefit occupational pensions to defined-contribution exposing employees to the risks of financial investment over the long-term, Pensions Policy Institute, The Changing Landscape of Pension Schemes in the Private Sector in the UK (2012), p.17; BHS scandal where inordinate dividends are paid at the expense of huge pension deficits, House of Commons Work and Pensions and Business, Innovation and Skills Committees, BHS Inquiry (June 2016) at

https://publications. parliament.uk/pa/cm201617/cmselect/cmworpen/54/54.pdf?utm source=54\&utm medi um=module\&utm campaign=modulereports, para 10, ch3.

${ }^{131}$ Department for Business, Energy and Industrial Strategy, Corporate Governance Reform: The Government's Response (August 2017) at

https://www.gov.uk/government/uploads/system/uploads/attachment data/file/640631/corporategovernance-reform-government-response.pdf.

${ }^{132}$ Ch12, John Plender, Capitalism: Money, Morals and Markets (London: Biteback Publishing 2015).

${ }^{133}$ BIS, The Kay Review of UK Equity Markets and Long-Term Decision Making (Final Report, July 2012).

${ }^{134}$ Corporate Values Strategy Group, Overcoming Short-termism: A Call for a More Responsible Approach to Investment and Business Management (New York: Aspen Institute Business and Society Programs, 2009), http://www.aspeninstitute.org/publications/overcoming-short-termism-call-more-responsible-approachinvestment-business-management.

${ }_{135}$ Caitlin Helms, Mark Fox and Robert Kenagy, 'Corporate Short-Termism: Causes and Remedies' (2012) 23 ICCLR 45; Emeka Duruigbo, 'Tackling Shareholder Short-Termism and Managerial Myopia' (2011-12) 100 Kentucky Law Journal 531. 
by the corporate sector. Bruner ${ }^{136}$ argues that the essentially private, shareholder-centric model of company law is legitimate in the UK as social concerns are addressed by the welfare state and social policy regulations, leaving it free for corporate law and governance to serve the needs of the company's private economic enterprise. The government's ability to use fiscal and welfare state measures has become increasingly limited due to the austerity measures imposed after the global financial crisis. ${ }^{137}$ The lacunae and deficiencies of corporate regulation are being exposed for not significantly moderating 'a-social' and 'bimoral' behaviour on the part of corporations. ${ }^{138}$

Section B now turns to the drivers that challenge the stability of regulatory capitalism.

\section{B. Regulatory Capitalism Challenged}

In this Section we argue that two major drivers exert pressure towards shifts in the tenets of regulatory capitalism. First the rise of voices that articulate perspectives on 'corporate social responsibility' (CSR), influencing policy and law for corporations. Second, the onset of the global financial crisis 2007-9 has introduced political disruptions that have had aftershock effects upon corporate regulation and reform.

\section{The Rise of Transnational Private Governance, Multi-stakeholder Initiatives and New Governance}

Civil society forces, such as the rise of non-governmental organisations (NGOs), ${ }^{139}$ have assumed an increasingly important voice in articulating the need for corporations, particularly multinational corporations, to assume responsibility commensurate with their social power and footprint ${ }^{140}$ and the need for them to act as 'social citizens' beyond legal compliance. ${ }^{141}$ Even as MNCs introduce investment and economic opportunities, they also exploit resources and externalise social harm. ${ }^{142}$ Civil society voices have arisen in the transnational sphere where there is a lack of global corporate regulation or extra-territorial regulation by nation states. ${ }^{143}$

\footnotetext{
${ }^{136}$ Christopher Bruner, "Power and Purpose in the 'Anglo-American' Corporation" (2010) 50 Virginia Journal of International Law 579.

${ }^{137}$ National debt was raised to bail-out UK banks, the budget deficit became challenging and austerity was introduced, 'Bank bail-out 'could send national debt soaring by $£ 1.5$ trillion', The Guardian (19 Feb 2009) at https://www.theguardian.com/business/2009/feb/19/national-debt-lloyds-hbos.

${ }^{138}$ Grietje Baars, “"Reform or Revolution”? Polanyian Versus Marxian Perspectives on the Regulation of The Economic' (2011) 62 NILQ 415.

139 Jonathan Doh and Terrence Guay, 'Globalization and Corporate Social Responsibility: How NonGovernmental Organizations Influence Labor and Environmental Codes of Conduct' (2004) 44 Management International Review 7; Dorothea Baur and Guido Palazzo, 'The Moral Legitimacy of NGOs as Partners of Corporations' (2011) 21 Business Ethics Quarterly 579.

${ }^{140}$ Rogers Orock, 'Less-told Stories about Corporate Globalization: Transnational Corporations and CSR as the Politics of (Ir)Responsibility in Africa' (2013) 37 Dialectical Anthropology 27; David Vogel, 'Taming Globalisation? Civil Regulation and Corporate Capitalism' in Coen et al (eds), The Oxford Handbook of Business and Government (2010), ch20.

${ }^{141}$ Andrew Crane, Corporations and Citizenship: Business, Responsibility and Society (Cambridge: CUP 2008); Jeremy Moon, Andrew Crane and Dirk Matten, 'Corporations and Citizenship in New Institutions of Global Governance' in Colin Crouch and C Maclean (eds.), The Responsible Corporation in a Global Economy (Oxford: OUP, 2011), pp203-224.

142 Janet Dine, 'Transnationals out of Control' in Governance of Corporate Groups (Cambridge: CUP, 2006).

${ }^{143}$ Tshuma, 'Hierarchies and Government' (2000).
} 
In this transnational space, a variety of actors offer voice, both critical and constructive, as well as pro-active initiatives to influence corporate behaviour. The space is first dominated by states, international organisations, networks of regulators and industry associations, ${ }^{144}$ but increasingly populated by third-party standard-setting bodies, civil society organisations, NGOs, forming a polycentric space ${ }^{145}$ for governance. Technological modernisation also facilitates social organisation, communications and cooperation for such common causes. In this space, various voluntary initiatives have been developed to secure corporate commitment to initiatives such as agendasetting for policy change, standard-setting for products, services or conduct, ${ }^{146}$ labelling or certification of organisations or their output, ${ }^{147}$ audit, procedural governance ${ }^{148}$ and dialogic mechanisms. ${ }^{149}$ As many initiatives differ from traditional regulatory law in terms of the nature of 'obligation' imposed, the 'precision' and 'enforcement' of such obligation, ${ }^{150}$ they are characterised as 'soft law'. Soft law typically mimicks but does not fully attain the traditional characteristics of state-based regulation. ${ }^{151}$ Many commentators have increasingly called upon the recognition of this body of soft law as 'transnational private regulation', ${ }^{152}$ consolidating its 'lawness' as a pluralist phenomenon, ${ }^{153}$ so that its causes may not obstructed by traditional frames for law and legality. ${ }^{154}$

144 chs 1.2, 2.3, 3, Piccioto, Regulating Global Corporate Capitalism (2011).

145 Larry Catá Backer, 'Transnational Corporations' Outward Expression of Inward Self-Constitution: The Enforcement of Human Rights by Apple, Inc.' (2013) 20 Indiana Journal of Global Legal Studies 805.

${ }^{146}$ EITC industry standards for conflict minerals tracing, Chang-Hsien Tsai and Yen-Nung Wu, 'What Conflict Minerals Rules Tell Us about the Legal Transplantation of Corporate Social Responsibility Standards without the State: From the United Nations to the United States to Taiwan' (2017) 38 Northwestern Journal of International Law and Business forthcoming.

${ }^{147}$ SA8000, the Ethical Trading Initiative, the Marine and Forest Stewardship Councils, the ISO14000 for environmental management, Karen Bradshaw Schulz, 'New Governance and Industry Culture' (2013) 88 Notre Dame L. Rev. 2515; Dara O’Rourke, 'Outsourcing Regulation: Analyzing Nongovernmental Systems of Labor Standards and Monitoring' (2003) 31 Policy Studies Journal 1; Aseem Prakash, The Voluntary

Environmentalists (Cambridge: CUP 2009).

${ }^{148}$ eg lender governance under the Equator Principles, Niamh O'Sullivan and Brendan O'Dwyer, 'Stakeholder Perspectives on a Financial Sector Legitimation Process: The Case of NGOs and the Equator Principles' (2009) 22 Accounting, Auditing \& Accountability Journal 553.

${ }^{149}$ A typology of 'private governance' initiatives, Tracey Roberts, 'Innovations in Governance: A Functional Typology of Private Governance Institutions' (2011) 22 Duke Envtl. L. \& Pol'y F. 67; Kenneth Abbott; Duncan Snidal, 'Strengthening International Regulation through Transmittal New Governance: Overcoming the Orchestration Deficit' (2009) 42 Vand. J. Transnat'I L. 501.

${ }^{150}$ Kenneth Abbott \& Duncan Snidal, 'Hard and Soft Law in International Governance' (2000) 54 International Organisation 421 on the paradigm spectrum for characterising hard or soft law.

${ }^{151}$ Alexia Brunet-Marks, 'The Right to Regulate' (2016) 38 U. Pa. J. Int'I L. 1; Harri Kalimo; Tim Staal, 'Softness in International Instruments - the Case of Transnational Corporations' (2014) 41 Syracuse J. Int'I L. \& Com. 257.

${ }^{152}$ Fabrizio Cafaggi, 'New Foundations of Transnational Private Regulation'(2011) 38 Journal of Law and Society 20; Colin Scott, Fabrizio Cafaggi \& Linda Senden, 'The Conceptual and Constitutional Challenge of Transnational Private Regulation' (2011) 38 Journal of Law and Society 1.

${ }^{153}$ Larry Catá Backer, 'Governance Polycentrism--Hierarchy and Order Without Government in Business and Human Rights Regulation' (2014) at http://ssrn.com/abstract=2373734; 'Theorizing Regulatory Governance Within its Ecology: The Structure of Management in an Age of Globalization' (2016) at https://ssrn.com/abstract=2783018; 'A Lex Mercatoria for Corporate Social Responsibility Codes Without the State? A Critique of Legalization Within the State Under the Premises of Globalization' (2017) 24 Indiana Journal of Global Legal Studies 115; Neil Walker and Gráinne de Búrca, 'Reconceiving Law and New Governance' (2007) at http://ssrn.com/abstract=987180; Peer Zumbansen, 'Transnational Legal Pluralism' (2010) 1 Transnat'l Legal Theory 141.

${ }^{154}$ Peer Zumbansen, 'Lochner Disembedded: The Anxieties of Law in a Global Context' (2013) 20 Indiana Journal of Global Legal Studies 29; Christine Parker, 'The Pluralization of Regulation' (2008) 9 Theoretical Inq. L. 349. 
The polycentric governance space and 'soft law' instruments for securing change in corporate behaviour constitute a 'transnational' new governance, ${ }^{155}$ characterised by diversity, inclusiveness, participation, interrelationships ${ }^{156}$ and the socialisation of the corporation within this fabric. ${ }^{157}$ In this manner, firm insularity can be opened up, and corporate accountability may be multichannelled, ${ }^{158}$ instead of narrowly focusing on markets and investors. There is increasing recognition of the potency of such bottom-up pressures. ${ }^{159}$ Civil society groups have successfully become part of many multi-stakeholder initiatives that shape corporate behaviour, ${ }^{160}$ albeit in an essentially contested space for governance.

Such institutional movements have been keenly noted by business. Concomitantly, businesses have also participated in the conceptualisation of CSR in order to frame it towards their interest. ${ }^{161}$ This conceptual stalemate ${ }^{162}$ is reflected in a 'governance' or political stalemate, ${ }^{163}$ as neither social forces nor business have fully captured the definition of CSR. ${ }^{164}$ Businesses have sought to characterise CSR as being consistent with the business case, whether financially-defined ${ }^{165}$ or

${ }^{155}$ Abbott \& Snidal, 'Strengthening International Regulation' (2009).
${ }^{156}$ Neil Gunningham, 'Regulatory Reform and Reflexive Regulation: Beyond Command and Control' in Inge Kau (ed), Reflexive Governance for Global Public Goods (Cambridge: MIT Press 2012).

${ }^{157}$ Heiko Spitzeck, 'Organizational Moral Learning: What, If Anything, Do Corporations Learn from NGO Critique?' (2009) 88 Journal of Business Ethics 157; Bettina Lange and Fiona Haines, 'Introduction' and Alexander Ebner, 'The Regulation of Markets: Polanyian Perspectives' in Bettina Lange, Fiona Haines and Dania Thomas (eds), Regulatory Transformations: Rethinking Economy-Society Interactions (Oxford: Hart 2015), chs $1,2$.

${ }^{158}$ Andreas Rasche, Frank de Bakker and Jeremy Moon, 'Complete and Partial Organizing for Corporate Social Responsibility' (2013) 115 Journal of Business Ethics 651; Ulrich Mueckenberger and Sarah Jastram, 'Transnational Norm-Building Networks and the Legitimacy of Corporate Social Responsibility Standards' (2010) 97 Journal of Business Ethics.

${ }^{159}$ Laura Hartman, Robert Rubin and KK Dhanda, 'The Communication of Corporate Social Responsibility: United States and European Union Multinational Corporations' (2007) 74 Journal of Business Ethics 373; David Detomasi, 'The Political Roots of Corporate Social Responsibility' (2008) 82 Journal of Business Ethics 807; Ulf Richter, 'Drivers of Change: A Multiple-Case Study on the Process of Institutionalization of Corporate Responsibility Among Three Multinational Companies' (2011) 102 Journal of Business Ethics 261.

${ }^{160}$ Nancy Vallejo and Pierre Hauselmann, 'Governance and Multi-stakeholder Processes' (IISD Paper, 2004). Egs include the Kimberley process for certifying conflict-free diamonds, Franziska Bieri and John Boli, 'Trading Diamonds Responsibly: Institutional Explanations for Corporate Social Responsibility' (2011) 26 Sociological Forum 501, the Forest Stewardship and Marine Stewardship Councils, Kees Bastmeijer and Jonathan Verschuuren, 'NGO-Business Collaborations and the Law: Sustainability, Limitations of the Law, and the Changing Relationship Between Companies and NGOs' in I Demirag (ed.), Corporate Social Responsibility (2005), pp314-329; Axel Marx and Dieter Cuypers, 'Forest Certification as a Global Environmental Governance Tool: What is the Macro-Effectiveness of the Forest Stewardship Council?' (2010) 4 Regulation and Governance 408; Lars Galbrundsen, 'The Emergence and Effectiveness of the Marine Stewardship Council' (2009) 33 Marine Policy 654. The Ethical Trading Initiative, Alex Hughes, Martin Buttle and Neil Wrigley, 'Organisational Geographies of Corporate Responsibility: A UK-US Comparison of Retailers' Ethical Trading Initiatives' (2007) 7 Journal of Economic Geography 491; Susanne Schaller, 'The Democratic Legitimacy of Private Governance' (INEF Report, 2007) at http://edoc.vifapol.de/opus/volltexte/2011/3476/pdf/report91.pdf.

${ }^{161}$ Krista Bondy, Jeremy Moon and Dirk Matten, 'An Institution of Corporate Social Responsibility (CSR) in Multi-National Corporations (MNCs): Form and Implications' (2012) 111 Journal of Business Ethics 281.

${ }^{162}$ Shallini Taneja, Pawan Kumar Taneja and Rajen Gupta, 'Researches in Corporate Social Responsibility: A Review of Shifting Focus, Paradigms, and Methodologies' (2011) 101 Journal of Business Ethics 343.

${ }^{163}$ Luc Fransen, 'Multi-stakeholder Governance and Voluntary Programme Interactions: Legitimation Politics In the Institutional Design of Corporate Social Responsibility' (2012) 10 Socio-Economic Review 163.

164 Taneja et al, 'Researches in Corporate Social Responsibility' (2011).

${ }^{165}$ The link between financial performance and corporate social performance is empirically inconclusive, Hoje Jo and Maretno Harjoto, 'The Causal Effect of Corporate Governance on Corporate Social Responsibility' (2012) 
wider. ${ }^{166}$ Businesses have also framed CSR as new management and self-regulatory tools ${ }^{167}$ that are purportedly more effective ${ }^{168}$ or efficient ${ }^{169}$ than government regulation. ${ }^{170}$

In this ideological contest over CSR, the intractability of debates such as between delineated responsibility ${ }^{171}$ and maximal responsibility for corporations, ${ }^{172}$ regulation ${ }^{173}$ and self-regulation, ${ }^{174}$ have become a fixture in the political economy of CSR. Commentators remain in disagreement on the characterisation of corporate citizenship, ${ }^{175}$ corporate purpose, ${ }^{176}$ and the means to change corporate behaviour. In this ideological contest, corporate codes of ethics are developed like chimeras that seem on the one hand to respond to social demands, ${ }^{177}$ but yet are completely selfregulating and often poorly enforced. ${ }^{178}$

106 Journal of Business Ethics 53; Marc Orlitzky, "Links between Corporate Social Responsibility and Corporate Financial Performance: Theoretical and Empirical Determinants" in J Allouche ed, Corporate Social

Responsibility (Palgrave Macmillan 2006), 41; Philip Baird, Pinar Geylani and Jeffrey Roberts, 'Corporate Social and Financial Performance Re-Examined: Industry Effects in a Linear Mixed Model Analysis' (2012) 109 Journal of Business Ethics 367; Stephen Brammer, Chris Brooks and Stephen Pavelin, "Corporate Social Performance and Stock Returns: UK Evidence from Disaggregate Measures" (2006) 35 Financial Management 97.

${ }^{166}$ resource-based perspective such as gaining social capital, consumer or employee loyalty, Dilek Cetindamar and Kristoffer Husoy, 'Corporate Social Responsibility Practices and Environmentally Responsible Behavior: The Case of the UN Global Compact' (2007) 76 Journal of Business Ethics 163; Ron Bird, Anthony Hall, Francesco Momentè and Francesco Reggiani, 'What Corporate Social Responsibility Activities Are Valued by the Market?' (2007) 76 Journal of Business Ethics 189; David Vogel, 'The Revival of Corporate Social Responsibility' and 'What is the Demand for Virtue?' in The Market for Virtue (NY: Brookings Institution Press 2005), chs 1 and 3.

${ }^{167}$ Kunal Basu and Guido Palazzo, 'Corporate Social Responsibility: A Process Model of Sensemaking' (2008) 33 Academy of Management Review 122'; Marta de la Cuesta González and Carmen Martinez, 'Fostering Corporate Social Responsibility through Public Initiative: From the EU to the Spanish Case' (2004) 55 Journal of Business Ethics 275.

${ }^{168}$ Tim Baines, 'Integration of Corporate Social Responsibility through International Voluntary Initiatives' (2009) 16 Indiana Journal of Global Legal Studies 223.

${ }^{169}$ Atle Blomgren, 'Is the CSR Craze Good for Society? The Welfare Economic Approach to Corporate Social Responsibility' (2011) 69 Review of Social Economy 495.

${ }^{170}$ Markus Kitzmueller and Jay Shimshack, 'Economic Perspectives on Corporate Social Responsibility' (2012)

50 Journal of Economic Literature 51.

${ }^{171}$ Timothy Devinney, 'Is the Socially Responsible Corporation a Myth? The Good, the Bad, and the Ugly of Corporate Social Responsibility' (2009) 23 Academy of Management Perspectives 44.

172 Klaus Leisinger, 'The Corporate Social Responsibility of the Pharmaceutical Industry: Idealism without Illusion and Realism without Resignation' (2005) 15 Business Ethics Quarterly 577; Michael Blowfield and Jedrzej Frynas, 'Setting New Agendas: Critical Perspectives on Corporate Social Responsibility in the Developing World' (2005) 81 International Affairs 499.

${ }^{173}$ Regina Kreide, 'The Obligations of Transnational Corporations in the Global Context. Normative Grounds, Real Policy, and Legitimate Governance' (2006) 4 Ethics and Economics 1; Mahmood Monshipouri, Claude Welch Jr. and Evan Kennedy, 'Multinational Corporations and the Ethics of Global Responsibility: Problems and Possibilities' (2003) 25 Human Rights Quarterly 965.

${ }^{174}$ Buhmann, 'Reflexive Regulation of CSR' (2010); Stavros Gadinis, 'Three Pathways to Global Standards: Private, Regulator, and Ministry Networks' (2015) 109 American Journal of International Law 1.

${ }^{175}$ PY Neron and W Norman, 'Citizenship, inc.': Do We Really Want Businesses to be Good Corporate Citizens?' (2008) 18 Business Ethics Quarterly 1, Donna Wood and Jeanne Logsdon, 'Business Citizenship as Metaphor and Reality' (2008) 18 Business Ethics Quarterly 51; Andrew Crane and Dirk Matten, 'Incorporating the Corporation in Citizenship: A Response to Néron and Norman' (2008) 18 Business Ethics Quarterly 27.

${ }^{176}$ Milton Friedman, 'The Social Responsibility of Business is to Increase its Profits' (NY Times Magazine, 13 September 1970) at http://www.umich.edu/ thecore/doc/Friedman.pdf; Andrew Keay, The Corporate Objective (Cheltenham: Edward Elgar, 2010).

${ }^{177}$ Ans Kolk and Rob van Tulder, 'Setting New Global Rules? TNCs and Codes of Conduct' (2005) 14 Transnational Corporations 1; Gunther Teubner, 'Corporate Codes in the Varieties of Capitalism: How Their Enforcement Depends on the Differences among Production Regimes (2017) 24 Ind. J. Global Legal Stud. 81; 
The claim to institutional change, though observed, is slow. Further, the polycentric governance space is far from harmonious, ridden with contests in ideology, values, power and methodology. Civil society organisations, NGOs and other socially-led groups face conflicts of interests ${ }^{179}$ and do not have consonant voices nor common agendas with each other or with state-led international organisations ${ }^{180}$ and corporate-led industry associations. There is a lack of clear authoritative or coordinative order in this governance space and the flourishing of myriad forms of soft law have not always translated into roadmaps for empirical implementation of changes to corporate behaviour.

\section{Mixed Achievements Observed in the UK}

The emerging nature of transnational governance has produced incremental institutional shifts. In the UK, corporations are increasingly attuned to 'social responsibility' concerns, but these are predominantly framed in terms of business 'risk' in relation to reputation and 'performance'. Hence, policy-makers introducing company law reforms in 2006 accept that a directors' duty to secure the 'success' of the company for the benefit of shareholders as a whole includes a duty to take into account of relevant stakeholder-facing and social responsibility matters. ${ }^{181}$ Investors are particularly called upon to consider 'environment, social and governance' (ESG) matters, aligning social expectations with their own interests. ${ }^{182}$ There is pronounced reliance on investor and market discipline for corporations' 'ESG' profiles, ${ }^{183}$ but we cannot blithely assume that investors act on behalf of enforcing social expectations or behave as social gatekeepers. ${ }^{184}$ The focus on the marketised framing for CSR has the potential to undermine the content of social demand in CSR. The marketised framing also has the effect of confining CSR to voluntary and self-regulatory measures, as legalisation may be regarded as inappropriate interventions into the 'market for virtue'. ${ }^{185}$

Policy-makers in the UK have been slow to consider regulatory policy in CSR, relying on corporate self-regulation and investor leadership to address corporate behaviour. The agnosticism of

with Anna Beckers, 'Expanding Constitutionalism' (2013) 20 Indiana Journal of Global Legal Studies 523; Jan Eijsbouts, 'Corporate Codes as Private Co-Regulatory Instruments in Corporate Governance and Responsibility and Their Enforcement' (2017) 24 Ind. J. Global Legal Stud. 181.

${ }^{178}$ Dirk Matten, Jeremy Moon and Krista Bondy, 'Multinational Corporation Codes of Conduct: Governance Tools for Corporate Social Responsibility?' (2008) 16 Corporate Governance: An International Review 294; Patrick Erwin, 'Corporate Codes of Conduct: The Effects of Code Content and Quality on Ethical Performance' (2011) 99 Journal of Business Ethics 535; Lutz Preuss, 'Codes of Conduct in Organisational Context: From Cascade to Lattice-Work of Codes' (2010) 94 Journal of Business Ethics 471. On enforcement deficit, Li-Wen Lin, 'Legal Transplants through Private Contracting: Codes of Vendor Conduct in Global Supply Chains as an Example' (2009) 57 American Journal of Comparative Law 711. Anna Beckers, Enforcing Corporate Social Responsibility Codes: On Global Self-Regulation and National Private Law (Oxford: Hart 2015).

${ }^{179}$ Fabrizio Cafaggi, 'The Many Features of Transnational Private Rule-Making: Unexplored Relationships between Custom, Jura Mercatorum and Global Private Regulation' (2015) 36 U. Pa. J. Int'I L. 875; Baur and Palazzo, 'The Moral Legitimacy of NGOs' (2011).

${ }^{180}$ Gregory Shaffer; Mark Pollack, 'Hard vs. Soft Law: Alternatives, Complements, and Antagonists in International Governance' (2010) 94 Minn. L. Rev. 706.

${ }^{181}$ S172, Companies Act 2006.

182 UNEPFI, Fiduciary Responsibility: Legal and Practical Aspects of Integrating Environmental, Social And Governance Issues Into Institutional Investment (Geneva: UNEPFI, 2009); Benjamin Richardson, 'Do the Fiduciary Duties of Pension Funds Hinder Socially Responsible Investment?' (2007) 22 Review of Banking and Financial Law 145.

183 Principle 4, UK Stewardship Code 2016.

${ }^{184} \mathrm{ch} 2$, Roger Barker and Iris H-Y Chiu, Corporate Governance and Investment Management (Cheltenham: Edward Elgar, 2017) and citations within.

${ }^{185}$ Vogel, The Market for Virtue (2005), chs 1, 3. 
regulators is an important reason for the slowness of institutional change. However, policy-makers have become interested in the innovative 'new governance' methodologies in many soft law initiatives. Such techniques seem to offer innovative and possible cost-reducing ways of introducing corporate regulation where warranted.

'New governance' methodologies are based on multi-stakeholder governance to change corporate behaviour. ${ }^{186}$ It is envisaged that the regulated subject ie the corporation would be subject to regulatory principles that incorporate more procedural flexibility, and work with a variety of 'governance' actors including regulators, markets and stakeholders in securing compliance, ${ }^{187}$ potentially overcoming the short-comings of traditional command-and-control regulation. In the UK, this was accepted by financial regulators (in line with international regulatory developments) ${ }^{188}$ in the area of regulating risk management by banks. Further, we also saw this implemented in the Corporate Homicide and Manslaughter Act 2007.

The implementation of new governance techniques in financial regulation has however resulted in spectacular regulatory failure in the global financial crisis 2007-9. This is largely because 'new governance' techniques were not implemented incorporating the multi-stakeholder ethos, and focused on investors and securities markets as governance actors. These have failed to exercise meaningful discipline ${ }^{189}$ resulting in banks being in fact devolved with self-regulation. Banks manipulated the 'flexible' regulatory standards to their advantage, and were relatively unchecked. ${ }^{190}$

Lacklustre implementation of 'new governance' techniques in the UK can also be seen in the Corporate Homicide and Manslaughter Act 2007. The Act progressed through a long period of gestation since policy reform recommended by the Law Commission in $1996^{191}$ after a number of fatal industrial accidents between 1986-9. ${ }^{192}$ Amidst political challenges to the policy change, the Law Commission's report was not taken up until 2000 after the New Labour government came to power. The Act is ultimately passed in 2007 to introduce a corporate manslaughter offence for public and private corporate bodies that cause death due to a gross breach of a duty of care to the victim/s, attributed to the way the organisation is managed or organised. ${ }^{193}$ The reform overcomes the limitations in case law which sought to attribute corporate liability to certain the minds and wills of certain individuals in corporations ${ }^{194}$ The new regulatory technique seems able to interrogate the 'inside' of the corporation in terms of poor management or organisation that results in harmful

\footnotetext{
${ }^{186}$ Parker, The Open Corporation (2002) and 'Meta-Regulation: Legal Accountability for Corporate Social Responsibility?' in Doreen McBarnet, Aurora Voiculescu and Tom Campbell (eds), The New Corporate Accountability: Corporate Social Responsibility and the Law (Cambridge: CUP, 2007).

${ }^{187}$ Neil Gunningham, 'The New Collaborative Environmental Governance: The Localization of Regulation' (2009) 36 Journal of Law and Society 145; with Darren Sinclair, 'Smart Regulation' in Drahos (ed), Regulatory Theory (2017), 133ff.

${ }^{188}$ The Basel II Capital Accord of 2006; Robert Weber, 'New Governance, Financial Regulation, and Challenges to Legitimacy: The Example of the Internal Models Approach to Capital Adequacy Regulation' (2010) 62 Administrative Law Review 783.

189 ch1, Iris H-Y Chiu, Regulating from the Inside: The Legal Framework for Internal Control in Banks and Financial Institutions (Oxford: Hart 2015).

${ }^{190}$ Cristie Ford, 'New Governance, Compliance, and Principles-Based Securities Regulation' (2008) 45 American Business Law Journal 1.

${ }^{191}$ Law Commission, Legislating the Criminal Law: Involuntary Manslaughter (London: HMSO, 1996).

192 Above, paras 1.12-1.16.

${ }^{193}$ Ss1-2.

${ }^{194}$ R. v P \& O European Ferries (Dover) Ltd, Central Criminal Court, 5 June 1990, [1991] 93 Cr. App. R. 72;

Transco plc v Her Majesty's Advocate, Appeal Court, High Court of Justiciary, 3 June 2003, [2005] B.C.C. 296.
} 
externally-facing conduct. ${ }^{195}$ This reform arguably connects a corporation's management to the prevention of social harm, introducing a form of disruption to the insular and economically-driven model of the corporation and its governance. ${ }^{196}$

The adoption of 'new governance' techniques in the Act has not introduced profound changes to corporate behaviour. First, the corporation remains 'free' to determine its internal management and systems and the regulatory regime does not involve social or stakeholder scrutiny into corporate behaviour on an ex ante basis. Second, the corporation is only called to account for its internal management and systems before the court when indicted for the occurrence of 'corporate homicide or manslaughter'. The judicial interrogation of internal management and systems is ex post in nature and has focused on precise pinpointing of senior management negligence. ${ }^{197}$ This narrow approach makes it difficult to pin liability upon large organisations with diffuse responsibility within. ${ }^{198}$

The achievements in regulatory policy in addressing the social dimensions of corporate behaviour have been relatively incremental before the onset of the global financial crisis 2007-9. The crisis and its aftermath has provided new opportunities for challenges to the stability of regulatory capitalism, culminating in the recent surge in legalisation of CSR issues discussed in Section C.

\section{Regulatory Capitalism Challenged by Global Financial Crisis and its Aftermath}

The global financial crisis 2007-9 saw the near failure of a number of US, UK and European banks that had taken excessive risks. Many were exposed to liquidity risks not prudently managed, ${ }^{199}$ or solvency risk due to holdings of complex (and ultimately toxic) securitised assets on their balance sheets. ${ }^{200}$ The marketised financial economy promotes herding in good times and excessive withdrawals in bad times, ${ }^{201}$ exacerbating stresses already faced by financial firms. ${ }^{202}$ As financialisation has brought about a state of private sector dominance in meeting the financial needs of states, business and households, ${ }^{203}$ many states found themselves in a position of having to bail out significant financial institutions in order to prevent the collapse of domestic financial systems. ${ }^{204}$ The crisis led to real economic damage, such as lost homes and jobs, and adversely affected the fiscal strength of governments, resulting in widespread austerity measures in the EU and UK, and a

\footnotetext{
195 Alice Belcher, “Corporate Killing as a Corporate Governance Issue” (2002) 10 Corporate Governance 47.

${ }^{196}$ Doreen McBarnet, 'Corporate Social Responsibility Beyond Law, Through Law, for Law' (2009), https://papers.ssrn.com/sol3/papers.cfm?abstract_id=1369305; Cynthia Williams, 'Corporate Social Responsibility and Corporate Governance' (2015) at https://papers.ssrn.com/sol3/Papers.cfm?abstract_id=2635473.

${ }_{197}$ R. v Cotswold Geotechnical Holdings Ltd [2011] EWCA Crim 1337.

${ }^{198}$ R. v Cornish (Errol) [2016] EWHC 779 (QB).

199 over-reliance on short-term market funding, eg Northern Rock.

${ }^{200}$ Howard Davies, The Financial Crisis: Who is to Blame? (Cambridge: Polity Press 2010); FSA, The Turner Review: A Regulatory Response to the Global Banking Crisis (2009).

${ }^{201}$ Emilios Avgouleas, 'The Global Financial Crisis, Behavioural Finance and Financial Regulation: In Search of a New Orthodoxy' (2009) 9 JCLS 23.

${ }^{202}$ Robert Kolb (ed), Lessons from the Financial Crisis: Causes, Consequences, and Our Economic Future (Chichester: John Wiley \& Sons 2010).

${ }^{203}$ Gerard Epstein (ed), Financialisation and the World Economy (Cheltenham: Edward Elgar 2006).

${ }^{204}$ Rosa Lastra, 'Systemic Risk, SIFIs and Financial Stability' (2011) 6 CMLJ 197; Iain MacNeil and Justin O'Brien (eds), The Future of Financial Regulation (Oxford: Hart 2010).
} 
loss of welfare. ${ }^{205}$ Social confidence in market capitalism in the UK has been severely disturbed, ${ }^{206}$ as reflected in (a) articulations of the ideological crisis of faith in the UK's capitalist model; and (b) political disruptions in the UK echoed across many other European countries.

The ideological crisis of faith in market capitalism has been expressed in intellectual calls to challenge the current model of market capitalism, in order to adjust towards an economic model more cognisant of the social needs for justice and stability. ${ }^{207}$ These voices reflect a culmination of underlying concerns that have built up for years in the UK economy- issues such as widening inequalities between the economic elite and ordinary citizenry, the stagnation of wages compared to profits made from financial capital ${ }^{208}$ and the marginalisation of stakeholders from business and policy. ${ }^{209}$ Indeed the 'Occupy' movement worldwide was a reflection of social discontent that has arisen to challenge the legitimacy of the capitalist model of market fundamentalism which has perpetuated social inequalities and divisions. ${ }^{210}$ This ideological crisis has not become revolutionary with worldwide crackdown of the Occupy movement. But policy-makers cognisant of the failings of financial markets sought to appease the public with international resolve ${ }^{211}$ to regulate banks and financial institutions more robustly. The determination in the US to bring the Dodd-Frank Act 2010 into force, and the comprehensive programme of institutional and regulatory reform in the $\mathrm{EU}^{212}$ and $\mathrm{UK}_{1}{ }^{213}$ which changed regulatory paradigms significantly, ${ }^{214}$ have found social resonance. This shift has not dethroned the private financial sector from continuing to be dominant in mediating worldwide financial needs for states, businesses and households, ${ }^{215}$ but a social truce seems to have been attained by the force of regulation asserting a new balance of power and legitimacy in the financialised market economy. The re-regulatory high in the aftermath of the global financial crisis 2007-9 is an important context for the increased legalisation of CSR to change corporate behaviour

205 Randall Germaine, 'Financial Order and World Politics: Crisis, Change and Continuity' (2009) 85 International Affairs 669; Sue Mew, 'Contentious Politics: Financial Crisis, Political-Economic Conflict, and Collective Struggles-A Commentary' (2013) 39 Social Justice 99.

${ }^{206}$ John Cioffi, 'After the Fall: Regulatory Lessons from the Global Financial Crisis' in David Levi-Faur (ed), Handbook on the Politics of Regulation (Cheltenham: Edward Elgar 2011), 642.

${ }^{207}$ Hay and Payne, Civic Capitalism (2015); Stiglitz, Freefall: America (2010), pp196-209; LC Bresser-Pereira, 'The Global Financial Crisis and a new Capitalism' (May 2010, Levy Economics Institute); K Möller, 'Struggles for Law: Global Social Rights as an Alternative to Financial Market Capitalism' in PF Kjaer, G Teubner and A Febbrajo (eds), The Financial Crisis in Constitutional Perspective (Oxford: Hart 2011).

${ }^{208}$ Ken-Hou Lin and Donald Tomaskovic-Devey, 'Financialization and U.S. Income Inequality, 1970-2008' (2013) 118 American Journal of Sociology 1284; Basak Kus, 'Financialisation and Income Inequality in OECD Nations: 1995-2007' (2012) 43 Economic and Social Review 477.

209 Institute for Public Policy Research, Time for Change (2017).

${ }^{210}$ ch1, Mads Andenas and Iris H-Y Chiu, The Foundations and Future of Financial Regulation (Oxford: Routledge, 2014).

${ }^{211}$ Eilis Ferran, Niamh Moloney and Jennifer Hill (eds), The Regulatory Aftermath of the Global Financial Crisis (Oxford: OUP 2013).

${ }^{212}$ Regulatory reform is based on protecting financial stability as a social good of newfound importance, and permeates micro and macro-prudential regulation, consumer protection etc, Andenas and Chiu, The Foundations (2014); MacNeil and O'Brien (eds), The Future of Financial Regulation (2010).

${ }^{213}$ The UK's reforms include ring-fencing retail banks from other financial activity, ch11, Andenas and Chiu, The Foundations (2014) and citations and a personal liability regime for bankers, Parliamentary Commission on Banking Standards, Changing Banking for Good (2013).

${ }^{214}$ Financial regulation has shifted away from market fundamentalism as regulators uphold public interest and introduce intrusive and pre-emptive regulations, Iris H-Y Chiu, 'Macro-prudential Supervision: Critically Examining the Developments in the UK, EU and Internationally' (2012) Law and Financial Markets Review 184; Andenas and Chiu, The Foundations (2014), chs 6, 7, 11-13.

${ }^{215}$ Christopher Arup, 'The Global Financial Crisis: Learning from Regulatory and Governance Studies' (2010) 32 Law and Policy 363. 
more generally. ${ }^{216}$ This trend is not limited to although pronounced in the EU and UK. ${ }^{217}$ At an international level, a similar appetite for the legalisation of CSR, such as in business and human rights, anti-bribery etc can also be detected. ${ }^{218}$

In the UK, the continuing motivation towards legalisation of CSR is also attributable to the sharpened political need to respond to social demand. Political sensitivity is sharpened towards social demand as the UK continues to experience political disruption that has followed from the global financial crisis. Instability in the consolidation of political power amongst major parties in the UK has intruded upon business-government relations, now in a more turbulent phase.

The New Labour government was ousted from power in the 2010 election following political mistakes made by the incumbent government defending the economic status quo. ${ }^{219} \mathrm{~A}$ coalition government was formed in the wake of a lack of parliamentary majority, between the Conservatives and Liberal Democrats, which oversaw most of the immediate post-crisis reforms and a period of austerity measures. Social sentiment has remained unstable as greater polarisation between the political right and left grew, ${ }^{220}$ and far-right elements have garnered a louder voice in political representation. ${ }^{221}$ The subsequent Conservative bare majority governments ${ }^{222}$ have been weak and besieged by divisions in social demand and opinions. The UK is experiencing a period of political instability such as highlighted in the highly divided Brexit referendum in 2016 and its continuing ramifications. Social discontent leading to political disruption is also played out in the UK's European neighbours, some of which are a response to the social fallout from austerity measures, ${ }^{223}$ and some of which reflect a social cry for paradigm shift and change in policy. ${ }^{224}$

In this landscape, holders of political power have turned to regulation ${ }^{225}$ to address many aspects of social discontent, especially vis a vis business. Such socially-facing regulation of business could placate voters, but they inevitably cause a shift in business-government relations. Could the current wave of legalisation in CSR matters signal a fundamental institutional shift in the tenets of regulatory capitalism, bridging the economically-driven and market-focused corporation with its ethical and social dimensions? Has the new legalisation ultimately 'hardened' the soft law of socially-driven initiatives? We turn to analyse the key reforms in Section C.

\footnotetext{
${ }^{216}$ Engobo Emeseh, Rhuks Ako, Patrick Okonmah, Obokoh, Lawrence Ogechukwu, 'Corporations, CSR and Self Regulation: What Lessons from the Global Financial Crisis?' (2010) 11 German Law Journal 230.

${ }^{217}$ The Dodd-Frank Act 2010 resulting in US SEC Final Rule 2012 at https://www.sec.gov/rules/final/2012/3467716.pdf on conflict minerals reporting.

${ }^{218}$ Christian Brütsch and Dirk Lehmkuhl, Law and Legalisation in Transnational Relations (Oxford: Routledge 2007). UN Guiding Principles for Business and Human Rights (2011), Larry Catá Backer, 'The Guiding Principles of Business and Human Rights at a Crossroads: The State, the Enterprise, and the Spectre of a Treaty to Bind Them All' (2014) at http://ssrn.com/abstract=2462844.

${ }^{219}$ Justin Pritchard, 'United Kingdom: The Politics of Government Survival' in Paul T'Hart and Karen Tindall (eds), Framing the Global Economic Downturn (Canberra: ANU Press 2009).

${ }^{220}$ Eg the election of extreme left Jeremy Corbyn as Labour party leader, while nationalist elements in the Conservative Party began to align with far right political parties supporting the UK's exit from EU membership. ${ }^{221}$ UK Independence Party.

${ }^{222}$ The Cameron government in 2015 and the May government formed in late 2016 after the Brexit Referendum.

${ }^{223}$ Social unrest and protests in Portugal, Greece and Spain.

${ }^{224}$ The French election in 2016 saw a new party and leader Emmanuel Macron defeat well-established parties; the rise of far-right politics in Hungary and Poland, and gains made by far-right political parties in the German and Austrian elections in 2017. The Spanish Catalan separatist movement, although quashed in mid-2017, also highlighted elements of political volatility.

${ }^{225}$ Tully Fletcher, 'The European Union: From Impotence to Opportunity?' in T'Hart and Tindall (eds), Framing the Global Economic Downturn (2009).
} 


\section{Post-Crisis Legalisation of CSR}

The corporate regulation reforms discussed in this Section could mark a significant institutional shift, as various 'socially-facing' aspects of corporate behaviour seem no longer to be left in the realm of soft law and self-regulation, but have found a place in regulatory law. This however does not mean that regulatory law embodies the substantive norms of conduct, or implementation and enforcement that reflect the nature of social demand. Crucially, 'new governance' techniques have again been brought in to effect such reforms. On the one hand, 'new governance' techniques embody a new ethos in corporations' governance relationships with stakeholders and not just the regulator/state. The employment of such techniques could mark a shift towards changing the nature of corporate regulation, allowing multi-stakeholderism and more social infusion into corporate regulation. On the other hand, 'new governance' techniques can also empower internal selfregulation by corporations, and are susceptible to devolution to corporates without due monitoring and accountability, as has occurred in the pre-crisis years. We observe that 'new governance' techniques have been employed in two key ways across a number of different regulatory reforms.

One technique extends corporate transparency to socially-facing issues and seems to invigorate securities markets as well as broader society in new roles of governance. We discuss the examples of the EU Non-financial disclosure Directive 2014 and the UK's Modern Slavery Act 2015. The other technique employs the 'new governance' approach of interrogating the inside of a corporation to enhance responsibility for preventing misconduct. These are: in relation to conflict minerals due diligence (EU Conflict Minerals Regulation 2017); bribery (Bribery Act 2010); tax evasion (Criminal Finances Act 2017) and the general enhancement of stakeholder voice in corporations (the UK's Business Energy and Industrial Strategy (BEIS) Department's reforms).

The achievements and limitations of recent corporate regulation reforms will be fleshed out by our analysis of the advancements (or otherwise) made by the employment of 'new governance' techniques. 'New governance' has the potential to challenge the economic insularity of corporate governance and objectives, and compel a form of socialisation of the corporation. However the very flexibility and malleability of 'new governance' techniques can be moulded to limit their challenge to the tenets of regulatory capitalism. 'Strong' forms of implementation of certain corporate regulation reforms could be adopted that bring about more profound paradigm shifts in the nature of corporate regulation in the UK, but these are ultimately not achieved. Instead the implementation in the UK continues to be shaped by the tenets of regulatory capitalism.

\section{Strong versus Weak Forms of 'New Governance' Implementation}

'Strong' forms of implementation of the recent corporate regulation reforms can signal decisive shifts away from the tenets of regulatory capitalism. Such implementation could promote the ethos of 'new governance' techniques in terms of infusing corporate objectives with social and ethical underpinnings, and promoting greater engagement between corporations with stakeholders in various formalised multi-stakeholder approaches in securing corporate compliance. ${ }^{226}$ These shifts would represent change from the market fundamentalist paradigms of corporate behaviour, as actors in governance could be non-market in nature, and social values may be elevated and not marginalised by 'market' values. We regard one or more of the following as representing a marked shift in corporate behaviour: re-orienting corporate objectives towards commitment to address CSR problems, re-orienting internal management and structures towards new ethics for supporting social

${ }^{226}$ Multi-stakeholder initiatives see $\mathrm{n} 160$. 
objectives, re-positioning corporate accountability towards a wide range of stakeholders, and the adoption of new, collaborative or pluralistic techniques of governance by the corporation.

On the contrary, weak forms of implementation would likely effect less marked or no departure from the tenets of regulatory capitalism. This could mean a continued subscription to the importance of incentive-based behaviour and market discipline, and limited or no adoption of multistakeholderism. Further, 'new governance' techniques that interrogate internal management structures, governance or procedures can be devolved to corporations and reduced to proceduralisation. Corporations can superficially adopt procedures or manipulate them to instrumental purposes, culminating in a form of 'organised hypocrisy' ${ }^{227}$ that does not really touch corporate culture. ${ }^{228}$ It has been observed that the deliberate promotion of multi-stakeholder governance in environmental governance has been unique and successful, a trend not replicated in other areas of CSR. ${ }^{229}$ Corporations devolved to interpret new governance reforms may manipulate regulatory freedoms in a calculative manner that does not attain social expectations, undermining the ethos of 'new governance' itself.

We first discuss the employment of 'new governance' techniques in interrogating internal management and procedures at corporations to combat bribery and tax evasion. Next, we discuss the use of these techniques, albeit in a more limited way, in addressing supply chain governance by corporations. Third, we turn to reforms based on corporate disclosure of CSR issues. Finally, we discuss the UK's reforms to improve stakeholder engagement with companies.

\section{(a) Enhancing Internal Interrogation into Corporations}

We first examine the Bribery Act 2010 and Criminal Finances Act 2017 to assess the UK's legislative efforts intervening into the internal organisation of corporations in order to change corporate behaviour 'from within'. Under both pieces of legislation, corporations are obliged to institute reasonable or adequate procedures in order to prevent bribery or tax evasion. This form of ex ante phrasing is different from ex post enforcement against acts of bribery and tax evasion. The obligation to prevent emphasises ongoing efforts and is aimed to change 'the way things are done' in the corporation via the introduction of a form of procedural regulation.

The Bribery Act 2010 introduces criminal liability for a corporation that fails to prevent bribery by any person associated with it in order to retain business or an advantage for the corporation. ${ }^{230}$ The corporation can only avoid liability if it has in place adequate procedures ${ }^{231}$ designed to prevent such conduct. Anti-bribery regulation delineates corporations' responsibility to prevent bribery even if they operate in a complex web of external institutional and cultural factors that demand corrupt payments. ${ }^{232}$ The Criminal Finances Act 2017 introduces for corporations an offence for failure to

\footnotetext{
${ }^{227}$ Kimberly Krawiec, 'Cosmetic Compliance and the Failure of Negotiated Governance' (2003) 81 Washington University Law Quarterly 487; Alwyn Lim and Kiyoteru Tsutsui, 'Globalization and Commitment in Corporate Social Responsibility: Cross-National Analyses of Institutional and Political-Economy Effects' (2012) 77 American Sociological Review 69.

${ }^{228}$ Steve Tombs, 'The Functions and Dysfunctions of Corporate Social Responsibility' in Baars (ed), The Corporation (2017), ch 22;

${ }^{229}$ Bindu Arya and Jane Salk, 'Cross-Sector Alliance Learning and Effectiveness of Voluntary Codes of Corporate Social Responsibility' (2006) 16 Business Ethics Quarterly 211.

${ }^{230}$ S7, Bribery Act 2010.

${ }^{231}$ Ministry of Justice, The Bribery Act 2010 Guidance at https://www.justice.gov.uk/downloads/legislation/bribery-act-2010-guidance.pdf.

${ }^{232}$ SD Beets, 'Understanding the Demand-Side Issues of International Corruption' (2005) 57 Journal of Business Ethics 65; Yanjing Chenet et al, 'Factors Influencing the Incidence of Bribery Payouts by Firms: A Cross-Country
} 
prevent tax evasion facilitated by a person associated with the corporation, whether such tax evasion is in relation to a liability to pay UK or foreign tax. The corporation can only avoid liability if it has put in place prevention procedures that are reasonable to be instituted. It is arguably a bold step for both Acts to impose criminal liability on corporations for 'failure to prevent', signalling the need for corporations to proactively look into their internal organisation, procedures and incentives in order to avoid liability.

In terms of substantive norms, anti-bribery norms have been enhanced in the Bribery Act while antitax evasion norms have been incrementally developed in other pieces of legislation. ${ }^{233}$ The Bribery Act has adopted an expansive definition of bribery, ${ }^{234}$ avoiding the route taken by the US Foreign Corrupt Practices Act whose exceptions to the definition of bribery reflect the capture of business interests. ${ }^{235}$ The Act has arguably achieved an unequivocal pronouncement on the social unacceptability of bribery ${ }^{236}$ after a protracted policy process challenged by business resistance. ${ }^{237}$ Under the Criminal Finances Act, 'tax evasion' is defined as 'cheating the public revenue' or 'knowingly engaged in a fraudulent scheme to evade $\operatorname{tax}^{\prime 238}$ and in relation to foreign taxes, relates to committing a tax evasion offence or breach of duty under foreign law. ${ }^{239}$ The illegal tax behaviour captured relates to precise norms of behaviour such as deceptive under-declaration or falsification of information so that tax liability is assessed incorrectly, but will also include tax avoidance behaviour that is established as 'abusive'. As Wolff points out, ${ }^{240}$ there is relatively minimal tax evasion by corporations, especially by multinational corporations whose financial transparency is heavily regulated, leaving little room for tax evasion. ${ }^{241}$ The increasing social outcry against corporate tax behaviour relates to tax avoidance ${ }^{242}$ or aggressive forms of it, i.e. legal structures and schemes that may appear to be complex and contrived, in order to minimise a corporation's tax burdens. ${ }^{243}$

Commentators have discussed how globalisation and easy access to low tax jurisdictions have greatly facilitated tax avoidance schemes for many multi-nationals, such as the use of transfer

Analysis' (2008) 77 Journal of Business Ethics 231; Kelly Martin et al, 'Deciding to Bribe: A Cross-Level Analysis of Firm and Home Country Influences on Bribery Activity' (2007) 50 Academy of Management Journal 1401.

${ }^{233}$ The Finance Act 2013 introduces an anti-abuse rule; also EU Tax Avoidance Directive, http://eurlex.europa.eu/legal-content/EN/TXT/?uri=uriserv:OJ.L_.2016.193.01.0001.01.ENG.

${ }^{234}$ Christopher Newman and Michael Macaulay, 'Placebos or Panaceas: Anglo-New Zealand Experiences of Legislative Approaches to Combatting Bribery' (2013) Journal of Criminal Law 482.

235 Jack Kaikati et al, 'The Price of International Business Morality: Twenty Years Under the Foreign Corrupt Practices Act' (2000) 26 Journal of Business Ethics 213.

${ }^{236}$ Laura Underkuffler, 'Defining Corruption: Implications for Action' in Robert Rotberg (ed), Corruption, Global Security, and World Order (NY: Brookings Institution Press 2009).

${ }^{237}$ Reform proposed since Law Commission, Legislating the Criminal Code: Corruption (1998) and Reforming Bribery (2008) at https://s3-eu-west-2.amazonaws.com/lawcom-prod-storage-

11jsxou24uy7q/uploads/2015/04/lc313.pdf, Cecily Rose, 'The UK Bribery Act 2010 and Accompanying Guidance: Belated Implementation of the OECD Anti-Bribery Convention' (2012) ICLQ 485.

238 S45.

239 S46.

${ }^{240}$ Lutz-Christian Wolff, 'Offshore Holdings For Global Investments of Multinational Enterprises: Just Evil?' (2015) JBL 445.

${ }^{241}$ Joel Slemrod, 'Cheating Ourselves: The Economics of Tax Evasion' (2007) 21 Journal of Economic Perspectives 25.

242 Montgomery Agnell, 'Tax Evasion and Tax Avoidance' (1938) 38 Columbia Law Review 80.

${ }^{243}$ Mihir Desai and Dhammika Dharmapala, 'Corporate Tax Avoidance and High Powered Incentives' (NBER Working Paper No. 10471, 2004), https://ssrn.com/abstract=541687. 
pricing schemes within the same group of companies, ${ }^{244}$ the use of offshore companies incorporated in tax havens to hold corporate assets or licences so that revenues are regarded to be earned offshore and subject to minimal tax. ${ }^{245}$ One of the most oft-cited examples is the 'double Irish Dutch sandwich' scheme used by Google to avoid paying corporate tax in the US. ${ }^{246}$ Although the ethicality of paying tax is not an absolute one ${ }^{247}$ and one can take the view that tax laws are rules-based in nature ${ }^{248}$ not representing fundamental norms or values such as compared to the protection of human rights or anti-corruption, the social offensiveness of aggressive corporate tax avoidance is not unfounded. Zucman ${ }^{249}$ argues that aggressive corporate tax avoidance has to date deprived most treasuries of $20 \%$ of their corporate tax receipts, which form a-third of most developed jurisdictions' revenues. Even if the net effect is a $6 \%$ loss in overall tax receipts by governments, this can impact upon public services, the deterioration of which is a major source of social discontent. ${ }^{250}$ Further, the loss of tax receipts could mean that governments have to borrow more and impose the fiscal burden upon ordinary citizens. Although some have argued that corporations, especially multinational ones, do not benefit from state provision of services or welfare and hence should not be asked to pay taxes to fund state expenditure, ${ }^{251}$ this argument only goes to reflect the insularity of the economically-driven globalised corporation which has no sense of citizenship or common burden-sharing with its communities. ${ }^{252}$ Many commentators see the need for corporations to be responsible in the relative ethicality of their tax behaviour, especially in light of their resourcefulness as compared to ordinary individuals. ${ }^{253}$

Tax behaviour has come under substantive reform since 2013. Until the passage of the Finance Act 2013 , there is no 'general anti-avoidance rule' ${ }^{254}$ in the UK. Tax law has been reformed to allow the HMRC to challenge 'tax abuse' arrangements ${ }^{255}$ by referring to a panel whose advisory opinion is to be recognised in court. ${ }^{256}$ Abusive tax behaviour is based on a 'double reasonableness' test that no reasonable person would regard the arrangement as a reasonable course of action, except to

\footnotetext{
${ }^{244}$ Don Hansen et al, 'Moral Ethics v. Tax Ethics: The Case of Transfer Pricing among Multinational Corporations' (1992) 9 Journal of Business Ethics 679.

${ }^{245}$ Steven Bank, 'The Globalization of Corporate Tax Law Reform' (2013) 40 Pepperdine Law Review 1307.

${ }^{246}$ Wolff, 'Offshore Holdings' (2015).

${ }^{247}$ Robert McGee, 'Three Views on the Ethics of Tax Evasion' (2006) 67 Journal of Business Ethics 15; Steven Bank, 'When did Tax Avoidance Become Respectable?' (2017) at https://ssrn.com/abstract=3014985.

${ }^{248}$ Agnell, 'Tax Evasion and Tax Avoidance' (1938); Wolff, 'Offshore Holdings' (2015).

249 Gabriel Zucman, 'Taxing across Borders: Tracking Personal Wealth and Corporate Profits' (2014) 28 Journal of Economic Perspectives 121.

${ }^{250}$ Hans Gribnau, 'Corporate Social Responsibility and Tax Planning- Not by Rules Alone' (2015) 24 Social and Legal Studies 225.

${ }^{251}$ Robert McGee, 'Some Thoughts on the Ethics of Parking Profits Offshore' (2014) 15 Journal of Accounting, Ethics and Public Policy, https://papers.ssrn.com/sol3/papers.cfm?abstract_id=2410020.

${ }^{252}$ Hans Gribnau and Ave Geidi-Jallai, 'Good Tax Governance: A Matter of Moral Responsibility and Transparency' (2017) 1 Nordic Tax Journal 70; Assaf Likhovski, "Training in Citizenship": Tax Compliance and Modernity' (2007) 32 Law and Social Inquiry 665.

253 Slemrod, 'Cheating Ourselves' (2007); Karen Brown, 'Comparative Regulation of Corporate Tax Avoidance: An Overview' in Karen Brown (ed), A Comparative Look at Regulation of Corporate Tax Avoidance (NY: Springer, 2012), 1.

${ }^{254}$ Sandra Eden, 'United Kingdom' in Brown (ed), A Comparative Look (2012), ch16.

255 The General Anti-Abuse Rule, Part 5, Finance Act 2013; HMRC guidance, https://www.gov.uk/government/uploads/system/uploads/attachment_data/file/611577/gaar-parts-a-c2017.pdf.

${ }^{256}$ S211, Finance Act 2013, Judith Freedman, 'Creating New UK Institutions for Tax Governance and Policy Making: Progress or Confusion?' (2013) British Tax Review 373.
} 
facilitate tax avoidance. ${ }^{257}$ Although a major step towards a general anti-avoidance rule, some commentators argue that the UK's approach falls slightly short. ${ }^{258}$ However, the EU Anti-Avoidance Directive 2016, yet to be fully implemented by Member States, likely combats many instances of corporate tax avoidance and provides a general anti-avoidance rule. The Directive looks set to develop substantive norms in unacceptable tax behaviour more widely in an unprecedented manner. ${ }^{259}$ Full implementation in the UK is however uncertain given the impending Brexit. ${ }^{260}$ In sum, there is a movement towards reforming tax behaviour norms but the full extent of these achievements remains to be seen.

Although key achievements in norm advancement have been attained in anti-bribery and anti-tax evasion, changes in corporate culture need to be achieved by both robust enforcement and ex ante corporate internalisation. We critically query whether the 'new governance' techniques to effect the 'responsibility to prevent' would result in mere devolution to corporations to institute internal procedures that are opaque to stakeholder and public accountability. This could undermine the ethos and potential of 'new governance' techniques, rendering the obligation to 'prevent' merely rhetorical, as the only meaningful enforcement would be ex post in nature.

First, we observe that the obligation to institute procedures under both Acts are in accordance with broad guidelines issued by the relevant government departments. The Ministry of Justice has issued procedural guidance in the manner of 6 broad principles to supplement the Bribery Act. ${ }^{261} \mathrm{~A}$ similar approach of Ministerial guidance is adopted in relation to the Criminal Finances Act. These guidances outline broad principles and corporations can use these as a basis for designing tailor-made changes to corporate operations or procedures. However, procedural or organisational reforms penetrate at different levels and need not show fundamental change. The resolve to change could reflect the corporation's incentives to manage the commercial impact of compliance or could reflect more normative embrace of social and public interest expectations. The premise for change affects the design of procedures including reforming leadership commitment, key business and operations processes, risk management and internal control. ${ }^{262}$ Procedural changes can also be less penetrative and more superficial, if designed merely to minimise legal risk while avoiding significant changes to the conduct of business. Procedural changes can be task-oriented such as multiplying documented channels, ${ }^{263}$ and one could remain sceptical as to real engagement with ethics, values ${ }^{264}$ or organisational culture. ${ }^{265}$

\footnotetext{
${ }^{257}$ S207(2).

${ }^{258}$ The anti-abuse regime can be perceived as equivalent to a general anti-avoidance rule, in light of Art 6, Anti-Tax Avoidance Directive, or relatively narrower, Andrés Moreno, 'A Pan-European GAAR? Some (Un)Expected Consequences of the Proposed EU Tax Avoidance Directive Combined with the Dzodzi Line of Cases' (2016) British Tax Review 143; Anzhela Cédelle, 'The EU Anti-Tax Avoidance Directive: A UK Perspective' (2016) British Tax Review 490.

259 Art 6.

${ }^{260}$ Cédelle, 'The EU Anti-Tax Avoidance Directive' (2016).

${ }^{261}$ The Bribery Act 2010 Guidance, Marta Muñoz de Morales, 'Corporate Responsibility and Compliance Programs in Australia' in Stefano Manacorda et al (eds), Preventing Corporate Corruption (Springer 2014), ch20.

${ }^{262}$ Angela Gorta, 'Research: A Tool for Building Corruption Resistance', Catherine Boardman and Vicki Klum, 'Building Organisational Integrity' in Peter Larmour and Nick Wolanin (eds), Corruption and Anti-Corruption (Canberra: ANU Press 2013), chs3, 5; David Hess, 'Catalyzing Corporate Commitment to Combating Corruption' (2009) 88 Journal of Business Ethics 781.

${ }^{263}$ Massimo Mantovani, 'The Private Sector Role in the Fight Against Corruption', Stefano Giavazzi, 'The ABC Model: The General Framework for an Anti-Bribery Compliance Program', 'The ABC Program: An Anti-Bribery
} 
The Acts have arguably devolved to corporations to determine their internal organisation and reform of procedures, as corporations are only required to introduce procedures where 'reasonable' and they remain the judge of what is 'reasonable' on an ex ante basis (although they have the burden to prove that their determination was correct). Although the Acts employ 'new governance' techniques, the essential 'new governance' ethos of enrolling multi-stakeholder governance is not pursued. ${ }^{266}$ Leaving corporations to implement their new compliance may render such post-crisis 'new governance' techniques again susceptible to the same pre-crisis problems discussed in Section B. LeBaron and Rühmkorf ${ }^{267}$ in an empirical study of the implementation of the Bribery Act 2010 find that many corporations have visibly changed their internal procedures and the terms and manner in which they conduct external relationships. These findings show that an extent of disruptive change has occurred from the 'inside' of corporations. However as this study did not engage with interviews with corporations, it does not shed light on whether procedural changes in written policies have deeply penetrated corporate culture and ethics.

The Serious Fraud Office's (SFO) enforcement of the Bribery Act against Rolls Royce in 2017 also sheds light on the extent to which 'new governance' regulatory techniques have really changed the nature of corporate regulation. In order to avoid prosecution for bribery carried out in China, Indonesia and a number of other countries, Rolls Royce agreed to appoint Lord Gold to monitor its internal procedural reform to prevent bribery in the future. Such monitoring and review is reported periodically to the SFO. ${ }^{268}$ The deferred prosecution agreement shows a preference for devolution to corporations to institute appropriate procedures, subject to a privatised form of monitoring by an expert.

Privatised implementation of corporate compliance can result in 'legal endogeneity ${ }^{269}$ (which refers to the self-legitimating effect of corporations' implementation of their own procedures and systems, resulting in de facto self-regulation). Under such an approach, how corporations deal with their ethical and compliance dilemmas remains opaque. In the wider context of global competition and temptations from tax havens, or the difficult contexts of doing business in corrupt jurisdictions, ethical dilemmas abound ${ }^{270}$ and there is social interest in scrutinising that corporate decisions do not compromise social objectives. The 'new governance' approach in the Bribery Act as enforced by the SFO has framed the governance space as revolving around the regulator and regulated, leaving little space for public and stakeholder scrutiny. We critically question why multi-stakeholder governance is not attempted. For example, Transparency International has developed a Checklist that

Compliance Program Recommended to Corporations Operating in a Multinational Environment', in Manacorda et al (eds), Preventing Corporate Corruption (2014), chs 3, 7, 8.

${ }^{264}$ Francesco Centonze, 'Public-Private Partnerships and Agency Problems: The Use of Incentives in Strategies

to Combat Corruption' in Manacorda et al (eds), Preventing Corporate Corruption (2014), ch4.

265 Johann Graf-Lambsdorff, 'The Organization of Anti-Corruption: Getting Incentives Right' in Rotberg (ed), Corruption (2009); Jeff Everett, Dean Neu and Abu Shiraz Rahaman, 'The Global Fight against Corruption: A Foucaultian, Virtues-Ethics Framing' (2006) 65 Journal of Business Ethics 1.

${ }^{266}$ Dimitri Vlassis, 'An Anticorruption Ethics and Compliance Program for Business: A Practical Guide' in Manacorda et al (eds), Preventing Corporate Corruption (2014), ch12.

${ }^{267}$ Genevieve LeBaron and Andreas Rühmkorf, 'Steering CSR Through Home State Regulation: A Comparison of the Impact of the UK Bribery Act and Modern Slavery Act on Global Supply Chain Governance' (2017) 8 Global Policy 15.

${ }^{268}$ Deferred Prosecution Agreement with Rolls Royce Plc (17 Jan 2017) at https://www.sfo.gov.uk/cases/rollsroyce-plc/.

${ }^{269}$ Lauren Edelman et al, "When Organizations Rule: Judicial Deference to Institutionalized Employment Structures" (2011) 117 American Journal of Sociology 888.

${ }^{270}$ AW Cragg, 'Business, Globalization, and the Logic and Ethics of Corruption' (1998) 53 International Journal 643. 
systematically directs companies to establish policies and management processes that would meet the broadly-worded procedural requirements in the Bribery Act and MOJ Guidance. ${ }^{271}$ Such a player could usefully act as part of an independent monitoring group for deferred prosecution arrangements. Multi-stakeholder governance may be resisted by business on the basis of commercial sensitivity but obligations of confidentiality and safeguards can be imposed. ${ }^{272}$

It may however be argued that multi-stakeholder governance is not the only means of securing corporate behavioural change. Indeed in the UK, there is a strong movement towards securing corporate culture and behavioural change in the banking sector after the global financial crisis 2007$9,{ }^{273}$ and these efforts are very much aimed at empowering regulators against the regulated, not coopting a wider scope of governance capacity. Regulatory enforcement and scrutiny can prevent legal endogeneity. However, the opacity in the regulator-regulated relationship can make regulatory efficacy an inscrutable matter, including obscuring any dangerous elements of regulatory capture or sympathy ${ }^{274}$ for the industry. For example, Wells ${ }^{275}$ criticises the SFO in its forbearance from enforcement where it felt constrained by fears that sanctions would damage the firm's viability. ${ }^{276}$ Further, the unique approach in financial regulation can in part be explained by the technical (and quantitative) nature of regulatory obligations, ${ }^{277}$ which stakeholders may find hard to scrutinise. Where social objectives underpin corporate regulation such as in anti-bribery, multi-stakeholder governance such as enrolling a panel of third-party bodies for engagement, feedback or even inspections, should be considered, as such can powerfully influence corporate consciousness and culture. ${ }^{278}$

\section{(b) Addressing Supply Chain Governance}

Globalisation and international trade has liberalised opportunities for worldwide sourcing, production and distribution of goods and services, but also brought about opportunities for exploitation of resources and labour. ${ }^{279} \mathrm{Global}$ sourcing can lead to fuelling regional conflicts over control of resources like oil and minerals, and exploitation of human beings in search of economic

\footnotetext{
${ }^{271}$ https://www.transparency.org/impact/.

272 see critique, Harry Gleckman, 'Multi-stakeholder Governance' (19 Jan 2016) at
} https://www.opendemocracy.net/harris-gleckman/multi-stakeholder-governance-corporate-push-for-newglobal-governance.

${ }^{273}$ House of Lords and House of Commons, Changing Banking for Good (2013) Vols I and II which culminated in the introduction of enhanced personal liability for senior managers. PRA and FCA, Strengthening Accountability in Banking: A New Regulatory Framework (July 2014); Strengthening Individual Accountability in Banking and Insurance: Amendments and Optimisations - PS12/17 (12 May 2017). Regulation also prescribes corporate governance and internal control target poor cultures in financial institutions. Basel Committee, Guidelines: Corporate Governance Principles for Banks (July 2015); EBA and ESMA, Guidelines on Internal Governance under Directive 2013/36/EU (26 Sep 2017), Chiu, Regulating (from) the Inside (2015), ch2, 3, 4, 5 and 6.

${ }_{274}$ Daniel Hardy, 'Regulatory Capture in Banking' (IMF Working Paper 2006), http://ssrn.com/abstract $=892925$.

${ }^{275}$ Celia Wells, 'Who's Afraid of the Bribery Act 2010?' (2012) JBL 420.

${ }^{276}$ Innospec, Wells, above.

${ }^{277}$ Eg microprudential regulation, Simon Gleeson, International Regulation of Banking: Capital and Risk Requirements (Oxford: OUP 2012).

${ }^{278}$ Corporate culture is increasingly an ethical and not performance-based concept, Rafael Rob and Peter Zemsky, 'Social Capital, Corporate Culture, and Incentive Intensity' (2002) 33 The RAND Journal of Economics 243; Marvin Brown, Corporate Integrity (Cambridge: CUP 2012), chs 1, 2, 3 and 7; Peter Rea et al, 'Corporate Ethics Can't Be Reduced to Compliance', Harvard Business Review (29 April 2016); Rosa Chun, 'What Aristotle Can Teach Firms About CSR', Harvard Business Review (12 Sep 2016).

${ }^{279}$ Kate Manzo, 'Modern Slavery, Global Capitalism \& Deproletarianisation in West Africa' (2005) 32 Review of African Political Economy 521; Kevin Bales, Disposable People: New Slavery in the Global Economy (California: Berkeley University Press, 1999). 
opportunities, ${ }^{280}$ such as through human trafficking, modern forms of slavery and abject labour conditions. ${ }^{281}$ Whether or not corporations are directly complicit in armed gangs' or gangmasters' evil exploits, they have to an extent been able to take advantage of cost advantages, by outsourcing and procuring on the basis of their global buying power. ${ }^{282}$ The abuses in such exploitation have been brought to light by the determined efforts of civil and non-governmental organisations, highlighting the pernicious effects of corporate indifference to the negative externalities in their supply chains.

UK and EU legislation have now started to address issues in the supply chain, after decades of soft law initiatives in the transnational sphere. These are in relation to the importation of conflict minerals, ${ }^{283}$ human trafficking and modern slavery ${ }^{284}$ (UK) and more generally, the protection of human rights. ${ }^{285}$

'New governance' techniques are employed in regulatory reforms, but they largely devolve supply chain governance to corporations themselves. To different extents in the Conflict Minerals Regulation 2017, the UK Modern Slavery Act 2015 and the non-financial disclosure of human rights impact under the EU Non-financial Disclosure Directive 2014, the corporation is expected to manage their supply chains based on their implementation of 'due diligence'. The Conflict Minerals Regulation imposes direct due diligence obligations but the Modern Slavery Act and EU Nonfinancial Disclosure Directive only require companies to disclose procedural aspects of supply chain governance.

First, it is noted that regulation has avoided articulating particular substantive norms, such as liability for sourcing conflict minerals or using trafficked labour or modern slaves in the supply chain. This is because the regulatory reforms avoid introducing 'outcomes' to be attained in terms of the desired social changes. It is argued that introducing bans for conflict minerals would result in an indiscriminate blow to legitimate economic activity in developing regions, ${ }^{286}$ hence substantive norms of conduct need to be considered carefully for unintended consequences. Under the Modern Slavery Act, it is a criminal offence for anyone to hold or require the performance of slave or compulsory labour. ${ }^{287}$ Unless a corporation is engaged in such practices, such as the abusive and illegal employment practices at SportsDirect which became the subject of a Parliament Inquiry, ${ }^{288}$ the criminal offence is unlikely to attach to a multinational corporation for practices occurring in its supply chain. There is also little prospect of the availability of tort class actions by victims of modern

\footnotetext{
${ }^{280}$ Chandran Nair, 'The Developed World Is Missing the Point About Modern Slavery' (20 June 2016) at Time.com at http://time.com/4374377/slavery-developed-developing-world-index-slave-labor/; Bales, 'Expendable People' (2000).

281 Galit Sarfarty, 'Shining Light on Global Supply Chains' (2015) 56 Harvard International Law Journal 419.

282 Jennifer Bair, 'The Corporation and the Global Value Chain' in Baars (ed), The Corporation (2017), ch 20.

283 EU Conflict Minerals Regulation 2017.

${ }^{284}$ Modern Slavery Act 2015.

285 Incorporating the principles in the UN Guiding Principles for Business and Human Rights (2011).

286 Jeff Schwartz, 'The Conflict Minerals Experiment' (2016) 6 Harvard Business Law Review 129; Katarzyna Kryczka, Sarah Beckers and Tineke Lambooy, 'The Importance of Due Diligence Practices for the Future of Business Practices in Fragile States' (2012) 9 European Company Law 125.

${ }^{287}$ S1.

${ }^{288}$ House of Commons Business Innovation and Skills Committee, Employment Practices at Sports Direct (July 2016) at

https://www.publications.parliament.uk/pa/cm201617/cmselect/cmbis/219/219.pdf?utm source=219\&utm medium=module\&utm campaign=modulereports.
} 
slavery in supply chains against the foreign multinational. ${ }^{289}$ It may be argued that corporations maintain different levels of leveraging power over their supply chains ${ }^{290}$ and an excessively high level of responsibility may be impracticable. However, soft law and transnational governance seem to have achieved more in introducing 'outcomes'-based norms, such as the Responsible Business Alliance's code of conduct for the electronics industry setting out extensive norms for humane employment conditions within the supply chain. ${ }^{291}$ Compared to norm advancement in anti-bribery and tax evasion, it is questioned why similar norms to 'prevent' the outcomes of suffering for individuals, or a form of joint or contributory liability for supply chain misconduct are not instituted. Such norm changes would have profound implications for multinationals in managing legal risk. ${ }^{292}$

The regulatory reforms focus on procedural governance, in the vein of 'new governance' techniques. The Conflict Minerals Regulation ${ }^{293}$ imposes due diligence obligations on importers of tin, tungsten, tantalum and gold. Importers also need to obtain third-party certification of compliance and make public disclosure on a yearly basis. ${ }^{294}$ However, these obligations are imposed on a narrow group of direct importers of the minerals into the $\mathrm{EU} .{ }^{295}$ If EU corporations produce output with these minerals sourced at some stage outside of the EU, they are not obliged to comply. ${ }^{296}$

In the absence of substantive norms that change corporate objectives or conduct, can the fulfilment of due diligence improve corporations' ethical considerations of being a good 'citizen' in conflictridden and fragile jurisdictions? It is questioned why a more precise substantive norm to require sourcing from conflict-free smelters cannot be legalised. ${ }^{297}$ The due diligence obligations to trace sources and undertake risk management are essentially devolved to corporations as a form of contractual management within its supply chain. ${ }^{298}$ In analysing the American counterpart to governing conflict minerals, ${ }^{299}$ commentators observe weak and cosmetic due diligence procedures and a general corporate indifference to their impact on fragile jurisdictions. ${ }^{300}$ In the absence of stronger substantive norms of outcomes or conduct, corporations' socially-facing motivations may conflict with their calculative and 'bimoral' tensions. ${ }^{301}$ These underlie the main hazards in devolving

\footnotetext{
${ }^{289}$ There is no doctrine of enterprise liability in the UK, Adams v Cape Industries plc [1990] Ch 433; Prest v Petrodel Resources Ltd [2013] UKSC 34.

290 Jennifer Bair, 'The Corporation and the Global Value Chain' in Baars (ed), The Corporation (2017), ch 20; Erika George and Scarlett Smith, 'In Good Company: How Corporate Social Responsibility Can Protect Rights and Aid Efforts to End Child Sex Trafficking and Modern Slavery' (2013) 46 International Law and Politics 55.

${ }^{291}$ The Electronic Industry Citizenship Coalition Code of Conduct at http://www.responsiblebusiness.org/media/docs/EICCCodeofConduct5_1_English.pdf.

${ }^{292}$ Section D.

${ }^{293}$ Regulation (EU) 2017/821.

294 Arts 3-7.

${ }^{295}$ Elif Härkönen, 'Conflict Minerals in the Corporate Supply Chain' (2018/9) European Business Law Review, forthcoming.

${ }^{296}$ The US requires corporations using conflict minerals in a key part of their production to disclose sourcing diligence, s1502, Dodd-Frank Act 2010 and Conflict Minerals Rule, 77 Fed. Reg. 56,274 (Sept. 12, 2012) (codified at 17 C.F.R. §§ 240.13p-1, 249b.400).

${ }^{297}$ Schwartz, 'The Conflict Minerals Experiment' (2016).

${ }^{298}$ The EU is developing recognition of third party due diligence schemes, which can promote multistakeholder governance.

${ }^{299}$ Disclosure obligation, n296.

${ }^{300}$ Christiana Ochoa \& Patrick Keenan, 'Regulating Information Flows, Regulating Conflict: An Analysis of United States Conflict Minerals Legislation' (2011) 3 Goettingen Journal of International Law 129.

${ }^{301}$ Kryczka et al, 'The Importance of Due Diligence' (2012).
} 
to corporations to manage the socially-facing issues in the commercial context of their supply-chain relations.

Third-party certification can however work as a form of gate-keeping under the Conflict Minerals Regulation. The certification has the potential to hold corporations accountable for their due diligence so that superficial compliance is avoided, adding implicit pressure for behaviour change. Existing players in the industry for certification services include the Conflict-free Smelter Programme, which can be expected to gain more formal recognition. Would certification be merely technical in nature, and would it take into account of the social justice footprint of the minerals trade? The Regulation comes into force in 2021, and developments should be watched.

On mandatory disclosure under the Modern Slavery Act and EU Non-financial Disclosure Directive, corporations are subject to a principally devolved and non-standardised implementation of due diligence.

Under section 54 of the Modern Slavery Act, certain commercial organisations ${ }^{302}$ must make mandatory disclosure yearly of a 'slavery and human trafficking statement' (the Statement) in order to provide transparency on the steps that a corporation has taken to ensure that its business and its supply chain are free from slavery and human trafficking. The Statement is to be made publicly available on the corporation's website. It is unlikely that section 54 would be interpreted as imposing a positive obligation of due diligence. Corporations' are to account for their own satisfaction that they have prevented the occurrence of modern slavery in their supply chains. Further, the mandatory statement avoids being too prescriptive as it refers to a non-exhaustive list of matters for reporting and companies do not have to include all of them. ${ }^{303}$ The Home Office's Practical Guidance for compliance with reporting under the Act emphasises that the Statement should encapsulate the steps taken by the company to prevent slavery and human trafficking in its supply chain, and that it should be in plain English, succinct and readily accessible.

The EU Non-financial Disclosure Directive 2014 requires large companies meeting certain conditions to include in the management report a non-financial statement, in order to understand its development, performance, position and impact of its activity, relating to environmental, social and employee matters, respect for human rights, anti-corruption and bribery matters. The nonfinancial statement should include a list of procedural matters in order to shed light on the above, including the company's due diligence policies, non-financial key performance indicators, the company's risk management policies and assessment of non-financial performance above. ${ }^{304}$

This is transposed in the UK which now requires the directors' Strategic Report, i.e. the narrative report produced by the Board, to include the non-financial statement. ${ }^{305}$ The list above seems prescribed and could introduce an indirect form of procedural regulation. ${ }^{306}$ This could be a stronger form of supply chain governance, compelling changes in corporations' procedures and their relationships with suppliers, bringing the regulatory regime closer to the one under the Conflict

\footnotetext{
302 s2, Modern Slavery Act 2015 (Transparency in Supply Chains) Regulations 2015.

${ }^{303}$ Home Office, Transparency in Supply Chains etc: A Practical Guide (2015) at https://www.gov.uk/government/uploads/system/uploads/attachment_data/file/471996/Transparency_in_S upply_Chains_etc__A_practical_guide_final_.pdf. ${ }^{304}$ Art 19a.

305 s414CA, Companies Act 2006 via the Companies, Partnerships and Groups (Accounts and Non-Financial Reporting) Regulations 2016.

${ }^{306}$ Iris H-Y Chiu, 'Unpacking the Reforms in Europe and UK Relating to Mandatory Disclosure in Corporate Social Responsibility: Instituting a Hybrid Governance Model to Change Corporate Behaviour?' (2017) 5 European Company Law 193.
} 
Minerals Regulation. However, we see no clear tendency towards treating the mandatory nonfinancial statement as a form of indirect procedural regulation. This is because the Commission Communication and the UK transposition frame the non-financial statement firmly within the familiar tenets of regulatory capitalism. The non-financial statement is addressed to investors, for them to exercise market discipline in non-financial issues.

Mandatory disclosure focuses on preliminary endeavours such as overcoming information asymmetry for the corporation concerned, ${ }^{307}$ and emphasises a predominantly internal and contractual form of management that is private to corporations and their suppliers. ${ }^{308}$ Although the Statement is of a primarily social orientation and not purposed as securities market disclosure, civil society scrutiny may be limited. The Statement is required to be concise, and the devolved implementation to corporations of their procedures may render such implementation essentially inscrutable by stakeholders. Devolved implementation obscures bimoral conflicts, opposing incentives and corporate culture, and could even legitimate a regressive form of behaviour, i.e. corporate-centred implementation to the exclusion of multi-stakeholder governance. A brief survey ${ }^{309}$ conducted of a small sample of Modern Slavery Statements in the first year of compliance shows that corporations disclose the existence of their internal codes of ethics and assert that they implement due diligence and other procedures. The corporations surveyed co-opt no multistakeholder guidance or partnership in fighting modern slavery. Civil society also has no standing for enforcement, as the Home Office is primarily responsible for enforcement. We are sceptical as to the potency of regulatory enforcement as the Home Office is tasked with more pressing enforcement responsibilities and we do not see the Home Office as an ongoing supervisor of companies' procedural systems and governance. Empirical research also finds that mandatory disclosure under the Modern Slavery Act has had little impact upon corporate procedures and behaviour. ${ }^{310}$

Such regulatory endeavours pale somewhat against initiatives in the transnational governance sphere which have developed multi-stakeholder standards and methodology for due diligence, such as third-party auditing or certification. Some examples are SHIFT-Mazars assurance standard for human rights management, ${ }^{311}$ the SA8000 certification standard for fair treatment of workers in workplaces. ${ }^{312}$ Soft law seems to have achieved clearer and more precise articulation of standards in supply chain governance, such as the Clean Clothes Model Code of Conduct. ${ }^{313}$ Regulation has avoided hardening substantive norms of social justice, and implements a regime to devolve to corporations the implementation of appropriate processes. This could even result in retardation in the development of social justice norms more generally in relation to labour practices and wage justice. ${ }^{314}$

\footnotetext{
307 Stephen Kim Park, 'Targeted Social Transparency as Global Corporate Strategy' (2014) 35 Northwestern Journal of International Law and Business 87.

${ }^{308}$ Shuangge Wen, 'The Cogs and Wheels of Reflexive Law \pm Business Disclosure under the Modern Slavery Act' (2016) 43 Journal of Law and Society 327.

${ }^{309}$ Chiu, 'Unpacking the Reforms' (2017).

${ }^{310}$ LeBaron and Rühmkorf, 'Steering CSR' (2017).

${ }^{311}$ SHIFT-Mazars, UNGP Reporting Framework Assurance Guidance and UNGP Reporting Framework

Assurance Guidance Indicators, at https://www.ungpreporting.org/wpcontent/uploads/UNGPRF_AssuranceGuidance.pdf and https://www.ungpreporting.org/wpcontent/uploads/UNGPRF_AssuranceGuidance_Indicators.pdf.

${ }^{312}$ http://www.sa-intl.org/index.cfm?fuseaction=Page.ViewPage\&PagelD=1689.

${ }^{313} \mathrm{https}$ //cleanclothes.org/resources/publications/clean-clothes-campaign-model-code-of-conduct/view.

${ }^{314}$ Janie Chuang, 'Exploitation Creep and the Unmaking of Human Trafficking Law' (2014) 108 American Journal of International Law 609.
} 
Indeed, the Home Office Practical Guidance for the Modern Slavery Act clearly states that mandatory disclosure is not tantamount to a warranty by the corporation that such crimes do not occur. This in effect sums up the limitations of the disclosure regulation- that in the absence of norms that deal with conduct or outcomes, disclosure and procedural regulation bear a weak connection to the issues of social justice sought to be addressed. ${ }^{315}$

Although the EU Directive also facilitates devolved implementation, the European Commission is keen to 'nudge' companies ${ }^{316}$ into adopting multi-stakeholder developed procedures for supply chain due diligence in three sectors: oil and gas, information technology and communications and recruitment agencies, a product of multi-stakeholder governance. ${ }^{317} \mathrm{~A}$ empirical study of nonfinancial statements produced by UK listed companies finds generally good quality disclosure, with the exception of human rights reporting, ${ }^{318}$ perhaps highlighting corporations' continued struggles within their supply chain.

\section{(c) Corporate Transparency in Social Responsibility Matters}

Corporate transparency in CSR matters has always been regarded as a key means to advance corporate engagement with social responsibility. Such disclosure is essential for overcoming information asymmetries with stakeholders, civil society, and securities markets. ${ }^{319}$ Voluntary CSR reporting has been on the rise as companies perceive reputational benefits in engaging with these matters. With the growth of the market for voluntary reporting, is there a need for mandatory disclosure? It could be argued that mandatory reporting is intended to signal the change in nature of non-financial reporting from being investor-centric ${ }^{320}$ to being substantively concerned with CSR as such. ${ }^{321}$ On that basis, mandatory disclosure is necessary in order to overcome the self-selecting biases of companies in voluntary reporting. However, there seems no explicit elevation of stakeholders in terms of corporate accountability to them, nor is there articulation of particular social goals that corporate transparency is to facilitate. Without a clear alternative basis for such mandatory disclosure, it has to be placed within its default context, i.e. serving investor-centric purposes in securities markets.

\footnotetext{
${ }^{315}$ Ozlem Arikan et al, 'Signposts or Weathervanes? The Curious Case of Corporate Social Responsibility and Conflict Minerals' (2015) at https://ssrn.com/abstract=3032498.

${ }^{316}$ The EU's does not strongly 'nudge' adoption of multi-stakeholder frameworks, as strong forms of 'nudge are often implemented as 'default unless opt out' options, Cass Sunstein and Richard Thaler, Nudge (Penguin, 2009).

${ }^{317}$ https://ec.europa.eu/anti-trafficking/publications/european-commission-sector-guides-implementing-unguiding-principles-business-and-human_en.

${ }^{318}$ Irene-marie Esser, lain MacNeil and Katarzyna Chalaczkiewicz-Ladna, 'Engaging Stakeholders in Corporate Decision-Making through Strategic Reporting: An Empirical Study of FTSE 100 Companies' (2017) at https://papers.ssrn.com/sol3/papers.cfm?abstract_id=3049203.

319 John Parkinson, 'Disclosure and Corporate Social and Environmental Performance: Competitiveness and Enterprise in a Broader Social Frame' (2003) 3 JJCLS 3; cf Björn Fasterling, 'Development of Norms Through Compliance Disclosure' (2012) 106 Journal of Business Ethics 73 who doubts that compelling disclosure causes companies to change from within.

${ }^{320}$ The UK has since 2006 required the directors' business review, a narrative report, to contain information on how environment and stakeholder issues relate to business performance, formerly s417, Companies Act. This is superseded by 5414A, the Strategic Report, which continues to be investor-centric, Iris H-Y Chiu, 'Reviving Shareholder Stewardship: Critically Examining the Impact of Corporate Transparency Reforms in the UK' (2014) 38 Delaware Journal of Corporate Law 983.

${ }^{321}$ Preamble 3.
} 
The UK transposition of the EU Directive subsumes the non-financial statement within the existing paradigms of corporate transparency/securities regulation. The statement is situated within the directors' Strategic Report, a narrative report centred upon explaining financial performance and business risks to investors. This is not inconsistent with the Directive's requirement that the statement be included in the management report, ${ }^{322}$ highlighting the Directive's ambivalence regarding the orientation of the statement. The Financial Reporting Council in the UK has further clarified that the non-financial statement, like the Strategic Report, should be guided by the standard of materiality, ${ }^{323}$ which frames the nature of disclosure according to what may be material to a reasonable investor. Although this is not inconsistent with the Commission Communication for implementation, ${ }^{324}$ the Communication also explicitly states the stakeholder-orientation of the statement. ${ }^{325}$ In sum, the EU seems ambivalent with regard to the market or social orientation of the statement, but the UK's implementation more clearly frames the statement to be investor-centric.

Disclosure regulation is often described as 'sunlight', being the 'best disinfectant' for behaviour that may otherwise be hidden. However, it is also a regulatory tool of minimum intrusion as it merely compels information to be released so that the market can determine the necessary economic discipline. ${ }^{326}$ There is even some investor interest in the financial implications of a corporation's compliance with the Modern Slavery Act. ${ }^{327}$ In relation to socially responsible behaviour, the mandatory disclosure tool suffers from several limitations. One is that mandatory disclosure is addressed to securities markets, and reliance is placed on investors to effect discipline for change in corporate behaviour. Investors are highly diverse, and even if some groups may monitor such disclosure and assess their relevance to investment decisions, ${ }^{328}$ other groups may be indifferent. ${ }^{329}$ This results in mixed signals and may be overall ineffective in sending a market message to corporations. Second, it is not certain what 'market discipline' is intended to be motivated by mandatory disclosure. If we expect investors to exercise 'voice' in their corporate governance roles for CSR, many mainstream institutional investors play a very limited role. ${ }^{330}$ If 'market discipline' comes in the form of 'exit', this merely drives corporate behaviour to manage their 'social responsibility' profile for the business case. ${ }^{331}$ Empirical research has found that social responsibility

\footnotetext{
${ }^{322}$ Art 19a.

${ }^{323}$ Financial Reporting Council, Guidance on the Strategic Report (June 2014), Section 5; p17, FRC, [Draft] Amendments to Guidance on the Strategic Report (Aug 2017) at https://www.frc.org.uk/getattachment/9e05c133-500c-4b98-9d76-497172387bea/;.aspx.

${ }^{324}$ Section 3.1, Communication from the Commission - Guidelines on non-financial reporting (methodology for reporting non-financial information) (2017) at http://eur-lex.europa.eu/legalcontent/EN/TXT/?uri=CELEX:52017XC0705(01).

${ }^{325}$ Section 3.5, above.

${ }^{326}$ Alan Page and RB Ferguson, Investor Protection (Cambridge: CUP 1992), 59-77.

327 Paul Cousins et al, 'The Shareholder Wealth Effects of Modern Slavery Reporting Requirements' (2017) at https://papers.ssrn.com/sol3/papers.cfm?abstract_id=2995175.

${ }^{328} \mathrm{eg}$ 'socially responsible funds', ch2.F, Barker and Chiu, Corporate Governance and Investment Management (2017). Such investors also vary in terms of caring for such issues per se or only as relates to financial performance.

${ }^{329}$ Alan Lewis and Carmen Juravle, 'Morals, Markets and Sustainable Investments: A Qualitative Study of 'Champions" (2010) 93 Journal of Business Ethics 483,

${ }^{330}$ Alexander Boersch, 'Doing Good by Investing Well? Pension Funds and Socially Responsible Investment: Results of an Expert Survey' (January 2010) Allianz Global Investors International Pension Paper No 1/2010 http://papers.ssrn.com/sol3/papers.cfm?abstract id=1607730.

${ }^{331}$ Martin Fougère and Nikodemus Solitander, 'Against Corporate Responsibility: Critical Reflections on Thinking, Practice, Content and Consequences' (2009) 16 Corporate Social Responsibility and Environmental Management 217.
} 
reports focused on the business case tends towards being narrow and individualistic, so mandating social disclosure to investors may not be consonant with meeting social expectations. ${ }^{332}$

We should not assume that a financially-driven and marketised framework for discipline and enforcement would clearly reshape corporate incentives and behavioural tendencies towards socially optimal objectives. Incentive-based, instrumental behaviour can trump normative premises $^{333}$ and the legalisation in the EU Directive could produce the counter-intuitive effect of undermining the social-ness of CSR norms that corporations should reckon with. However, the opposite can also occur, ie the infusion of the salience of CSR norms into investment marketplaces incrementally introduces re-orientation of market perceptions with social ones, ${ }^{334}$ producing a holistic integrative effect that can overcome the myopic and calculative culture of modern institutional investment. This requires more significant institutional change, which Strine ${ }^{335}$ for example doubts would happen. ${ }^{336}$ The UK transposition of the ambivalent premises in the EU Directive has avoided paradigm change, although some see the usefulness of generally overcoming information asymmetries for the purposes of informing civil society or stakeholder activism. ${ }^{337}$

\section{(d) UK Reforms towards Stakeholder Inclusiveness in Corporate Governance}

The complaint so far of a lack of paradigm change is based on observations of the corporate-centric and market-centric premises and implementation of recent corporate regulation reforms, signalling no significant shift from the tenets of regulatory capitalism. There is however an emerging corporate law reform in the UK that holds promise for more fundamental change, as formalised stakeholder engagement with corporations will be implemented. This can usher in an era of multistakeholderism in corporations, shifting away from investor centricity, and generally mitigating the weaknesses in regulatory reforms discussed above.

The Department of Business, Energy and Industrial Strategy has embarked on legislative and soft law reforms that purport to recalibrate in stakeholders' favour, their relations with corporations. ${ }^{338}$ It may be criticised that most reforms are in soft law ${ }^{339}$ and the legislative initiatives only enhance shareholders' roles. The cynical view is that the reforms resist institutional change by giving stakeholders illusory and non-consequential 'improvements'. In the alternative we may view the confused premises of these reforms as representing a genuine struggle towards institutional change.

\footnotetext{
${ }^{332}$ Stefan Tengblad and Claes Ohlsson, 'The Framing of Corporate Social Responsibility and the Globalization of National Business Systems: A Longitudinal Case Study' (2010) 93 Journal of Business Ethics 653.

333 Jiwei Ci, 'Justice, Freedom, and the Moral Bounds of Capitalism' (1999) 25 Social Theory and Practice 409.

${ }^{334}$ The Polyanian vision, Karl Polyani, The Great Transformation (Beacon Press, $2^{\text {nd }}$ ed, 2002, original 1944), Part II; Carlo Trigilia, Economic Sociology (Oxford: Blackwell 2002), ch1, Fred Block and Margaret F Sommers, 'Beyond the Economistic Fallacy: The Holistic Social Science of Karl Polanyi' in Theda Skocpol (ed), Vision and Method in Historical Sociology (Cambridge: CUP 1984), ch3. cf Kurtuluş Gemici, 'Karl Polanyi and the Antinomies of Embeddedness' (2008) 6 Social Economic Review 5.

${ }^{335}$ Leo Strine Jnr, 'Human Freedom and Two Friedmen: Musings on the Implications of Globalization for the Effective Regulation of Corporate Behavior' (2007) at http://ssrn.com/abstract=1024506.

${ }^{336}$ ch1-3, Barker and Chiu, Corporate Governance and Investment Management (2017).

337 John Conley; Cynthia Williams, 'Engage, Embed, and Embellish: Theory versus Practice in the Corporate Social Responsibility Movement' (2005) 31 J. Corp. L. 1.

${ }^{338}$ Corporate Governance Reform: The Government's Response (August 2017) at https://www.gov.uk/government/uploads/system/uploads/attachment data/file/640631/corporategovernance-reform-government-response.pdf at pp24-36.

${ }^{339}$ Discussed below.
} 
First, employees are the only group of stakeholders given more voice in strategic decision-making at companies. This is to be achieved in one of three ways: nominating a non-executive director dedicated to employee issues, nominating an employee-director or setting up an employee advisory council to advise the Board. ${ }^{340}$ These changes are proposed to be made to the Corporate Governance Code. Code standards are nevertheless subject to 'comply-or-explain' by listed companies, and the Code is founded on shareholder primacy. ${ }^{341}$ Shareholders could in theory agree to companies deviating from these measures if they accept companies' explanations. ${ }^{342}$

Next, directors are to report explicitly on how they have engaged with stakeholder-focused considerations in the Strategic Report. ${ }^{343}$ Such disclosure is however pursuant to the directors' duty in s172 of the Companies Act, which hold directors to account to shareholders for how they 'promote the long-term success of the company'. It remains uncertain how the continued maintenance of the shareholder primacy focus in such stakeholder-related reporting would advance stakeholder inclusiveness in corporate considerations. ${ }^{344}$ Best practices for stakeholder engagement would be developed in the form of soft law led by professional and industry associations. ${ }^{345}$ One of the associations involved in this initiative is the Investment Association representing investors. Can such leadership advance stakeholder engagement with companies on stakeholders' terms?

Finally, the BEIS will introduce legislative reform to compel companies to disclose the pay ratios of their UK employees. This seems to meet the social demand for scrutinising inequalities in reward that have developed in the corporate sector. However, such disclosure is primarily targeted at shareholders who scrutinise this as part of their role in approving directors' remuneration packages. ${ }^{346}$ Stakeholders seem disengaged from this issue, ${ }^{347}$ which ought to be of social orientation and importance.

Soft law has been employed for stakeholders to be 'relationised' within corporate governance, while company law continues to feature the dominance of shareholders. However, the institutional stature of soft law cannot be totally underestimated. Stakeholder engagement is now a 'best practice' implicitly supporting polycentric principles of governance. Even if the confused and contesting premises between shareholder-centric and stakeholder theories of the corporation are not reconciled overtly, ${ }^{348}$ space is formally opened up for stakeholders to exert pressure to 'resocialise' the corporation, and the state has finally taken on a coordinating role to facilitate this. Nevertheless, the implementation of stakeholder engagement reforms runs the risk of being merely proceduralised. Stakeholder engagement can be carried out in superficial manner and do not

\footnotetext{
${ }^{340}$ FRC, Proposed Revisions to UK Corporate Governance Code (Dec 2017) at
} https://www.frc.org.uk/getattachment/bff48ee6-4fce-4593-9768-77914dbf0b86/Proposed-Revisions-to-theUK-Corporate-Governance-Code-Appendix-A-Dec-2017.pdf.

${ }^{341}$ Section A.

${ }^{342}$ It has however been argued that shareholders tend to hold companies to 'compliance' as a shorthand for best practice, Marc Moore, 'Whispering Sweet Nothings: The Limitations of Informal Conformance in UK Corporate Governance' (2009) 9 JCLS 77.

${ }^{343}$ FRC, Proposed Revisions (2017).

${ }^{344}$ Many commentators do not see s172 as a shift from shareholder primacy, Richard Williams, 'Enlightened Shareholder Value in UK Company Law' (2012) 35 UNSW Law Journal 360; Andrew Keay,"Section 172(1) of the Companies Act 2006: an Interpretation and Assessment" (2007) 28 Company Lawyer 106; Elaine Lynch, 'Section 172: A Ground-Breaking Reform of Director's Duties, or the Emperor's New Clothes?' (2012) Company Lawyer 196.

${ }^{345}$ Institute of Chartered Secretaries and Administrators: The Governance Institute, Investment Association.

${ }^{346}$ S439A, Companies Act 2006.

${ }^{347}$ Paras 1.28-1.35, BEIS, Corporate Governance Reform (2017).

${ }^{348}$ Arikan et al, 'Signposts or Weathervanes' (2015). 
fundamentally affect business strategy or corporate culture. ${ }^{349}$ It remains uncertain if the domination of investor-centric input into the development of stakeholder engagement can crucially weaken such development; and whether implementation would be devolved largely to the corporation.

The Table below sums up the achievements in each regulatory reform that indicates an institutional shift, mapped against limitations showing adherence to the tenets of regulatory capitalism.

\begin{tabular}{|c|c|c|}
\hline & $\begin{array}{l}\text { Indicators of Institutional } \\
\text { Change }\end{array}$ & $\begin{array}{l}\text { Indicators of Institutional } \\
\text { Adherence }\end{array}$ \\
\hline Conflict Minerals Regulation & $\begin{array}{l}\text { 1. Direct procedural } \\
\text { regulation } \\
\text { 2. compulsory third party } \\
\text { monitoring and } \\
\text { potential for formally } \\
\text { recognised multi- } \\
\text { stakeholder } \\
\text { governance }\end{array}$ & $\begin{array}{l}\text { 1. no overt articulation of } \\
\text { social objectives (A) }\end{array}$ \\
\hline Bribery Act 2010 & $\begin{array}{l}\text { 1. } \begin{array}{l}\text { articulation of } \\
\text { obligation to prevent } \\
\text { bribery }\end{array} \\
\end{array}$ & $\begin{array}{ll}\text { 1. } & \text { devolution to } \\
\text { corporations to design } \\
\text { systems and } \\
\text { procedures (B) } \\
\text { 2. lacks reference to } \\
\text { coordinating multi- } \\
\text { stakeholder } \\
\text { governance (C) }\end{array}$ \\
\hline Criminal Finances Act 2017 & $\begin{array}{l}\text { 1. } \begin{array}{l}\text { articulation of } \\
\text { obligation to prevent } \\
\text { tax evasion }\end{array} \\
\text { 2. reform of tax } \\
\text { behavioural norms }\end{array}$ & $\begin{array}{l}\text { 1. } B \\
\text { 2. } C\end{array}$ \\
\hline $\begin{array}{l}\text { BEIS Corporate Governance } \\
\text { Reforms 2017-18 }\end{array}$ & 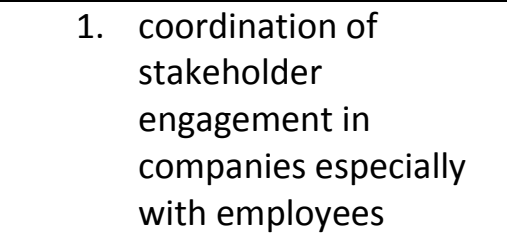 & $\begin{array}{l}\text { 1. investor-centric } \\
\text { reporting (D) } \\
\text { 2. use of soft law not } \\
\text { corporate law } \\
\text { 3. possibly B }\end{array}$ \\
\hline $\begin{array}{l}\text { EU Non-financial Disclosure } \\
\text { Directive } 2014 \text { transposed in } \\
\text { UK Companies Act }\end{array}$ & 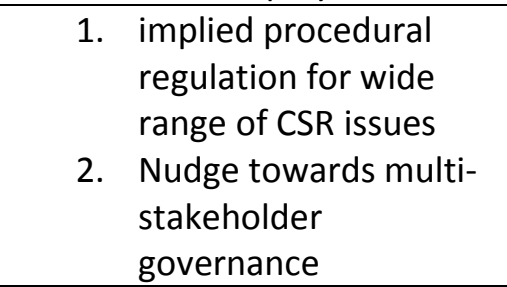 & $\begin{array}{ll}1 . & D \\
2 . & C\end{array}$ \\
\hline Modern Slavery Act 2015 & $\begin{array}{l}\text { 1. Socially-facing } \\
\text { mandatory disclosure }\end{array}$ & $\begin{array}{ll}\text { 1. } & \mathrm{A} \\
\text { 2. } & \mathrm{B} \\
\text { 3. } & \mathrm{C}\end{array}$ \\
\hline
\end{tabular}

${ }^{349}$ Jean-Pascal Gond, 'Reconsidering the Critical Corporate Social Responsibility Perspective through French Pragmatic Sociology: Subverting Corporate Do-Gooding for the Common Good?' in Baars (ed), The Corporation (2017), ch 23. 
Next, we account for why regulatory reforms in legalising aspects of CSR are underwhelming and the implications of addressing the precise locations of weakness.

\section{Why Legalisation of CSR is Underwhelming and Concluding Thoughts}

Calleiss and Renner argue that ${ }^{350}$ soft law hardens when its function arrives at a state of 'stabilisation of normative expectations'. We may expect the legalisation of aspects of CSR reflects 'mature' moments of recognition for certain aspects of CSR, viz as public goods, as stabilising certain sociallyfacing norms of conduct for corporations, and for corporate accountability to be provided in innovative ways including the engagement of multi-stakeholder governance. ${ }^{351}$ Although the flexibility of soft law is often positively regarded, Short argues that 'falling back' on self or soft regulation is often a manifestation of a regulatory 'void'- the lack of resolve to address problems. ${ }^{352}$ Commentators support the formalisation of public policy in CSR, such as into regulation, as one or more of the following benefits can be attained:

(a) leadership in setting public interest objectives; ${ }^{353}$

(b) the orchestration of governance capacity on the part of public and private actors by assigning regulatory responsibilities, and coordinating a systematic and coherent framework, supported by regulatory intervention to moderate imbalances in power and influence; ${ }^{354}$

(c) support for the implementation of changes by private actors, whether by corporations or by other third parties in frameworks of governance, such as co-regulation; ${ }^{355}$ and

(d) the provision or coordination of enforcement capacity in different and multi-faceted ways in order to secure corporate compliance and behavioural change. ${ }^{356}$

However, if we measure the achievements of the corporate regulation reforms discussed in Section $C$ against the expectations stipulated above, the achievements seem underwhelming.

\footnotetext{
${ }^{350}$ Gralf-Peter Calliess \& Moritz Renner, 'From Soft Law to Hard Code: The Juridification of Global Governance' (2009) 22 Ratio Juris 260.

${ }^{351}$ Reinhard Steurer, 'The Role of Governments' (2010; Jette Knudsen, 'Bringing the State Back in? US and UK Government Regulation of Corporate Social Responsibility (CSR) in International Business' (2014) at http://ssrn.com/abstract=2541002; Natasha Tusikov, 'Transnational Non-State Regulatory Regimes' in Drahos (ed), Regulatory Theory (2017); Laura Albareda, Josep M. Lozano and Tamyko Ysa, 'Public Policies on Corporate Social Responsibility: The Role of Governments in Europe' (2007) 74 Journal of Business Ethics 391.

352 Jodi Short, 'Self-Regulation in the Regulatory Void: "Blue Moon" or "Bad Moon"?' (2013) 649 Annals of the American Academy of Political and Social Science 22, Blomgren, 'Is the CSR Craze Good' (2011).

${ }^{353}$ Colin Scott, 'The Regulatory State and Beyond' in Drahos (ed), Regulatory Theory (2017), ch16; Benedict Sheehy, 'Private and Public Corporate Regulatory Systems: Does CSR Provide a Systemic Alternative to Public Law' (2016) 17 UC Davis Business Law Journal 1; Robert MacQuordale, 'Towards More Effective Legal Implementation of Corporate Accountability for Violations of Human Rights' (2009) 103 Proceedings of the Annual Meeting (American Society of International Law) 288.

${ }^{354}$ Abbott \& Snidal, 'Strengthening International Regulation' (2009).

${ }^{355}$ Colin Scott, 'Beyond Taxonomies of Private Authority in Transnational Regulation' (2012) 13 German L.J. 1329; Gunningham, 'Regulation: From Traditional to Cooperative' in Van Slyke et al (eds), Oxford Handbook of White Collar Crime (2016).

${ }^{356}$ Yishai Blank; Issi Rosen-Zvi, 'The Persistence of the Public/Private Divide in Environmental Regulation' (2014) 15 Theoretical Inq. L. 199; Kevin Jackson, 'The Normative Logic of Global Economic Governance: In Pursuit of Non-Instrumental Justification for the Rule of Law and Human Rights' (2013) 22 Minn. J. Int'I L. 71;
} 
First, the Table in Section C shows that the articulation of substantive obligations is limited, and has only been more clearly achieved in anti-bribery and anti-tax evasion. In the absence of clearer and stronger normative premises, task-based and procedural requirements may produce compliance of an underwhelming quality, as corporations can revert to their own centricity and market-facing priorities in order to determine their implementation. It remains questionable if there is clear engagement with ethics, social expectations and corporate culture.

The lack of genuine social advancement in some CSR areas may be attributed to the still-contested nature of these issues in the polycentric transnational sphere. ${ }^{357}$ The 'hardening' or 'legalisation' of substantive norms is limited in two ways. One is that substantive norms that are legalised reflect already-achieved consensus in inter-governmental organisations, advancing nothing much that is novel. The due diligence obligations in conflict minerals, anti-bribery and the fight against tax evasion using offshore havens, have been developed extensively over the decades under the OECD. ${ }^{358}$ In particular, norm advancement in anti-bribery and tax evasion were achieved due to economic interests at play. US business economic interests were key to the US government adopting the Foreign Corrupt Practices Act 1977 and its sustained championing for international convergence which was finally achieved in the late 1990s at the OECD. ${ }^{359}$ Further, anti-tax evasion norms have arguably been advanced in the UK after the global financial crisis due largely to the government's interests in shoring up its fiscal weaknesses. ${ }^{360}$ The alignment of economic interests and political strength are key to policy choice and norm changes. Such are still relatively lacking in relation to supply chain responsibility, as the implications for multinational corporations would be an undesirable culmination in enterprise liability and an expansion of their legal risks. ${ }^{361}$ Hence, in relation to corporations' responsibility to prevent human rights violations or manage supply chain misconduct, norms are much more contested in terms of the scope of corporate responsibility in a network of commercial relations.

We also see the lack of advancement in regulatory commitment to norms of social justice as being due to the lack of multi-stakeholder governance or a Habermasian ${ }^{362}$ discourse in the polycentric space regarding the future of our capitalism model and institutions. Although we see 'new governance' techniques employed to an unprecedented extent to reach into the organisation and procedures of corporations, much of regulatory implementation results in devolution to the

\footnotetext{
${ }^{357}$ Section B.

${ }^{358}$ OECD Due Diligence Guidance for Responsible Supply Chains of Minerals from Conflict-Affected and HighRisk Areas established since 2011; the OECD Convention on Combating Bribery of Foreign Public Officials in International Business Transactions since 1997, and the OECD's work on a Model Tax Convention since 1993, and combatting tax havens, Harmful Tax Competition (1998),

http://www.oecd.org/tax/transparency/44430243.pdf.

${ }^{359}$ Kenneth Abbott, 'Rule-making in the WTO- Lessons from Bribery and Corruption' (2001) Journal of International Economic Law 275; Elizabeth Spahn, 'Implementing Global Anti-Bribery Norms: From The Foreign Corrupt Practices Act to the OECD Anti-Bribery Convention to the U.N. Convention Against Corruption' (2013) 23 Indiana International and Comparative Law Review 1.

${ }^{360}$ Iris H-Y Chiu, "From Multilateral to Unilateral Lines of Attack: The Sustainability of Offshore Tax Havens and Financial Centres in the International Legal Order" (2016) 31 Connecticut Journal of International Law 177.

${ }^{361}$ MNCs are able to structure risky activities in subsidiaries in order to protect parent companies from liability. In the UK this is helped by the persistent refusal of UK courts to allow enterprise liability by applying the 'lifting of the corporate veil', Adams v Cape Industries plc [1990] Ch 433; Prest v Petrodel Resources Ltd [2013] UKSC 34.

362 Jürgen Habermas, Between Facts and Norms: Contributions to a Discourse Theory of Law and Democracy (Cambridge, Mass: MIT Press, 1996); Communication and the Evolution of Society (Beacon Press, 1979), Moral Consciousness And Communicative Action (MIT Press, 1990), The Theory of Communicative Action, Vol. 2: Lifeworld and System: A Critique of Functionalist Reason (Boston: Beacon Press, 1985).
} 
corporation or scrutiny by securities markets. Corporations manage their supply chain governance as an extension to their contractual governance, and it is queried if the continued dominance of the commercial context would bring any fundamental change to corporations' incentive-based behaviour. There is still too much deference to the corporation and its self-regulating capacity, and misplaced reliance on capital markets to develop an aligned 'market for virtue'. The continued failure of regulatory incorporation of the 'new governance' ethos of polycentricity could be a key impediment to institutional shift. Except for the mandatory requirement of third-party auditing under the Conflict Minerals Regulation, there is reference to multi-stakeholder governance in other regulatory reforms discussed.

Legalisation has avoided hardening or recognising existing civil society initiatives in CSR. The lack of recognition for the achievements in transnational governance, ${ }^{363}$ or advancement in promoting the ethos of multi-stakeholder governance can be attributed to the incompatibility of such governance with the capitalist institution of the UK's liberal market economy. This capitalist model eschews the notion of regulators taking a lead in coordinating polycentric governance. Orchestrating such coordination may be seen to be intervening with the freedoms of constituents who should be allowed to express their discipline in the open 'market for virtue'. However, the 'market' commercialises 'virtue', and may not price virtue in alignment with its social and public interest aspects. Moreover, the 'market for virtue' is not a level playing field. Voices derived from capital (investors) are accorded with more legitimacy, and civil society voices can be marginalised, enjoying no real freedom of exercising discipline. It may be necessary for states and regulators to coordinate stakeholder and civil society involvement more explicitly ${ }^{364}$ in order to (a) signal the public interest orientation of CSR issues (and not merely their commercial or market relevance) and (b) compensate for stakeholders' and civil society's relatively disadvantaged positions in exercising governance. Pluralistic and inclusive frameworks can be key to fostering discourses that may give rise to substantive changes in values, norms or goals. ${ }^{365}$

In the UK, stakeholder-focused reforms in soft law that are afoot in corporate governance hold some promise for introducing a formal multi-stakeholder governance space surrounding corporations. This reform may be important for future advancement of CSR causes. Employees are to be formally organised in order to input voice into corporate governance, and research has shown that they are keen to advance labour justice and human rights issues. ${ }^{366}$ Other stakeholder engagement mechanisms to be developed in soft law can also form the basis for developing multi-stakeholder governance over CSR issues. However, there are a few caveats in viewing such stakeholder reforms as being equivalent to the coordination of polycentric/multi-stakeholder governance in CSR issues. Stakeholder engagement mechanisms are likely focused on each group's interests and may not be focused on particular CSR issues. Such engagement mechanisms may be seen as private dialogues and communications, and may not revolve around public interest or the provision of public goods. In the absence of the 'public' coordinating hand, the dynamics and coordination within such mechanisms would become private interactions, and 'governance' potential or capacity may not be galvanised.

It may be argued that civil society groups should also improve their transparency, social accountability, representativeness and legitimacy in order to become truly credible actors in the

\footnotetext{
${ }^{363}$ Section B.

${ }^{364}$ Gunningham, 'The New Collaborative Environmental Governance' (2009).

${ }^{365}$ Fasterling, 'Development of Norms Through Compliance Disclosure' (2012).

${ }^{366}$ Aguilera et al, 'Putting the S Back' (2007).
} 
multi-stakeholder governance space. These issues are acknowledged, ${ }^{367}$ but the imperfections of such groups can be worked upon. Civil society groups may be comparably lacking in capacity, resources and sophistication vis a vis corporations and their industry associations. ${ }^{368}$ Indeed states and regulators should engage with them more and look into capacity-building. Such imperfections cannot amount to good reason for their marginalisation.

Corporate regulation reforms in legalising aspects of CSR seemed to hold promise in changing the nature of corporate regulation. We acknowledge the incremental achievements but remain underwhelmed. We account for the limitations in recent regulatory reforms by highlighting their institutional adherence. The institutional account of recent corporate regulation reforms within the paradigm of regulatory capitalism explains the limited achievements in the implementation of 'new governance' and the purported legalisation of CSR. This institutional account nevertheless pinpoints precise locations of impediments to institutional change, so as to inspire resolve to face the heavier lifting ahead.

\footnotetext{
${ }^{367}$ Baur and Palazzo, 'The Moral Legitimacy of NGOs' (2011); Colin Scott, 'Beyond Taxonomies' (2012); Deirdre Curtin and Linda Senden, 'Public Accountability of Transnational Private Regulation: Chimera or Reality?' (2011) 38 Journal of Law and Society 163.

${ }^{368}$ Jon Burchell and Joanne Cook, 'Sleeping with the Enemy? Strategic Transformations in Business - NGO Relationships Through Stakeholder Dialogue' (2013) 113 Journal of Business Ethics 505; Doh and. Guay, 'Globalization and Corporate Social Responsibility' (2004).
} 


\section{about ECGI}

The European Corporate Governance Institute has been established to improve corporate governance through fostering independent scientific research and related activities.

The ECGI will produce and disseminate high quality research while remaining close to the concerns and interests of corporate, financial and public policy makers. It will draw on the expertise of scholars from numerous countries and bring together a critical mass of expertise and interest to bear on this important subject.

The views expressed in this working paper are those of the authors, not those of the ECGI or its members. 


\section{ECGI Working Paper Series in Law}

\section{Editorial Board}

Editor

Consulting Editors

Editorial Assistants
Luca Enriques, Allen \& Overy Professor of Corporate Law, Faculty of Law, University of Oxford

John Coates, John F. Cogan, Jr. Professor of Law and Economics, Harvard Law School

Paul Davies, Senior Research Fellow, Centre for Commercial Law, Harris Manchester College, University of Oxford

Horst Eidenmüller, Freshfields Professor of Commercial Law, University of Oxford

Amir Licht, Professor of Law, Radzyner Law School, Interdisciplinary Center Herzliya

Roberta Romano, Sterling Professor of Law and Director, Yale Law School Center for the Study of Corporate Law, Yale Law School

Tamas Barko , University of Mannheim

Sven Vahlpahl, University of Mannheim

Vanessa Wang, University of Mannheim 


\section{Electronic Access to the Working Paper Series}

The full set of ECGI working papers can be accessed through the Institute's Web-site (www.ecgi.org/wp) or SSRN:

Finance Paper Series http://www.ssrn.com/link/ECGI-Fin.html

Law Paper Series http://www.ssrn.com/link/ECGI-Law.html 